\title{
PROPOSAL
}

\section{KORELASI PENGUASAAN KOSAKATA \\ DENGAN KETERAMPILAN MENULIS TEKS DESKRIPSI SISWA KELAS VII DI SMP NEGERI 2 KECAMATAN GUNUNG OMEH}

Diajukan untuk memenuhi tugas perkuliahan Metode Penelitian Pembelajaran Bahasa Indonesia Yang Dibina oleh Prof. Dr. Syahrul R., M. Pd.

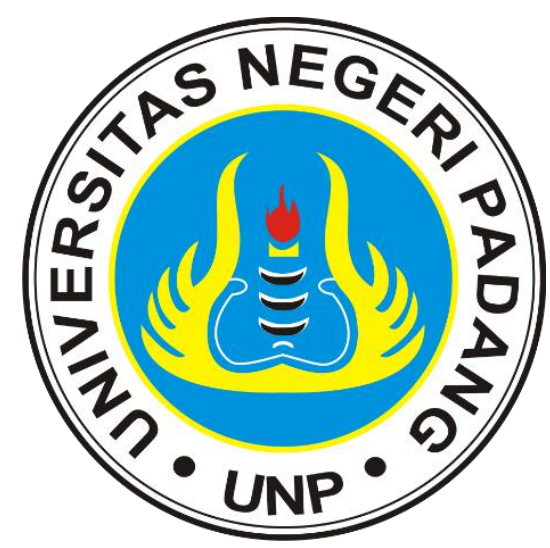

Oleh:

MARTA ZENI

19016027

PROGRAM STUDI PENDIDIKAN BAHASA INDONESIA JURUSAN BAHASA DAN SASTRA INDONESIA DAN DAERAH

FAKULTAS BAHASA DAN SENI

UNIVERSITAS NEGERI PADANG 


\section{KATA PENGANTAR}

Syukur Alhamdulillah penulis ucapkan kepada Allah SWT atas segala limpahan anugerah dan rahmat yang diberikan-Nya sehingga proposal ini dapat diselesaikan sebagaimana yang diharapkan. Tidak lupa Shalawat serta salam kepada Rasulullah Muhammad SAW yang diridhoi Allah SWT. Proposal ini berjudul" Korelasi Penguasaan Kosakata dengan Keterampilan Menulis Teks Deskripsi Siswa Kelas VII di SMP Negeri 2 Kecamatan

Gunung”. Proposal penelitian ini ditulis guna memenuhi salah satu persyaratan Mata Kuliah Metode Penelitian Bahasa Indonesia, Program StudiPendidikan Bahasa Indonesia, Jurusan Bahasa dan Sastra Indonesia dan Daerah, Fakultas Bahasa dan Seni Universitas Negeri Padang. Penulisan proposal ini tidak lepas dari bimbingan dan motivasi dari banyak pihak. Melalui kesempatan ini dengan segala hormat dan kerendahan hati, penulis mengucapkan banyak terima kasih kepada Bapak Prof. Dr. Syahrul R., M.Pd. selaku dosen pembimbing mata kuliah Metode Penelitian Bahasa Indonesia, orang tua yang sudah mendukung, dan kepada teman - teman yang sudah memberikan semangat dan saran.

Penulisan proposal ini tentunya masih jauh dari kata sempurna, baik dari segi isi maupun penyajiannya. Oleh karena itu penulis sangat mangharapkan kritik dan saran demi penyempurnaan skripsi ini. Akhir kata, semog skripsi ini dapat bermanfaat bagi pembaca.

Padang, 21 November 2021

Penulis 


\section{DAFTAR ISI}

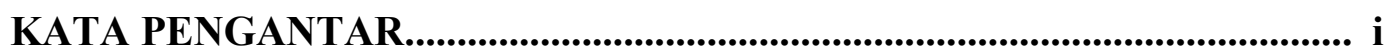

DAFTAR ISI.................................................................................................. ii

BAB 1 PENDAHULUAN........................................................................ 1

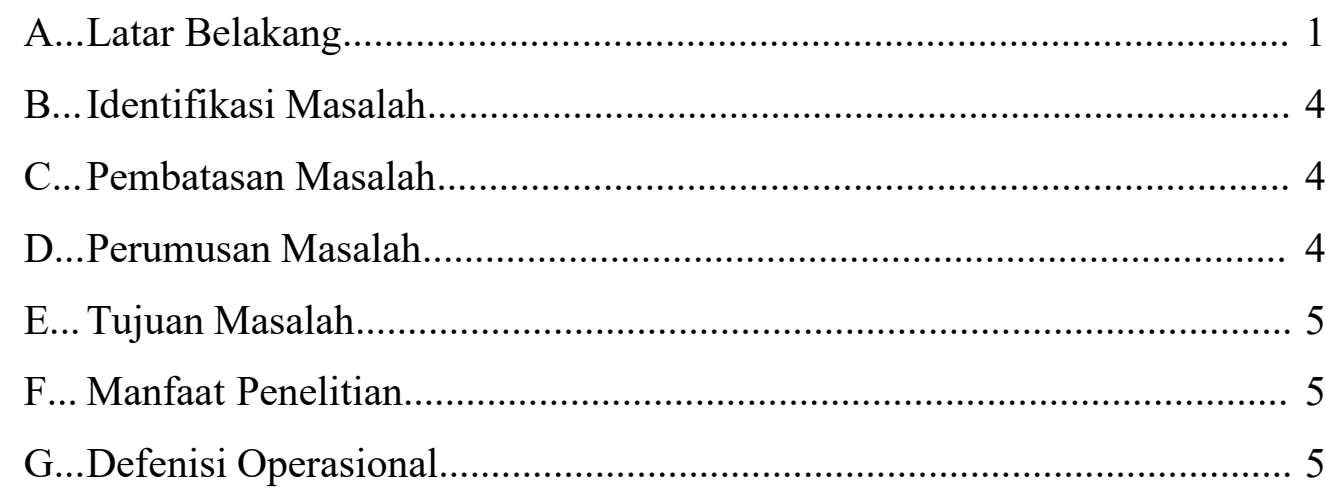

BAB II KAJIAN PUSTAKA.............................................................................. 7

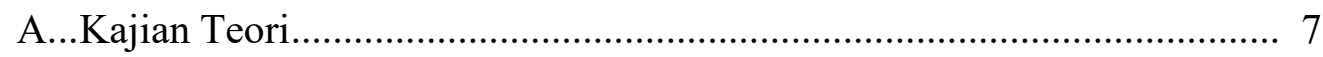

1. Keterampilan Menulis Teks Deskripsi................................................... 7

a. Pengertian Teks Deskripsi............................................................. 7

b. Struktur Teks Deskripsi................................................................. 8

c. Isi Teks Deskripsi......................................................................... 9

d. Ciri Umum Teks Deskripsi.............................................................. 9

e. Penggunaan Bahasa Teks Deskripsi................................................... 10

f. Langkah-langkah Menulis Teks Deskripsi.......................................... 12

g. Contoh Teks Deskripsi ...................................................................... 14

2. Penguasaan Kosakata........................................................................ 15

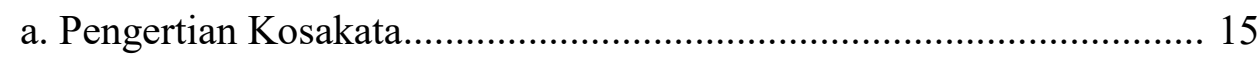

b. Jenis - jenis Kosakata.................................................................... 16

c. Tujuan Pembelajaran Kosakata.......................................................... 19

d. Pengembangan Kosakata................................................................ 19

3. Korelasi Penguasaan Kosakata dengan Keterampilan

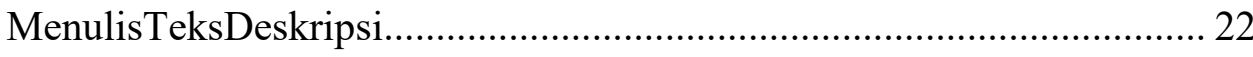


B...Penelitian yang Relevan...............................................................23

C...Kerangka Konseptual..................................................................... 24

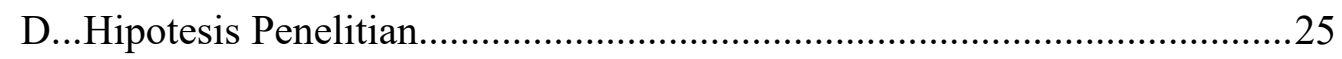

\section{BAB III METODOLOGI PENELITIAN}
A...Jenis dan Metode Penelitian.............................................................. 26
B...Populasi dan Sampel...........................................................................26

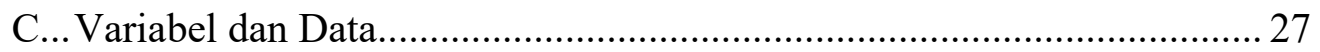
D...Intrumen Penelitian.........................................................................28
E... Teknik Pengumpulan Data............................................................. 32
F... Uji Prasyarat Analisis........................................................................ 32

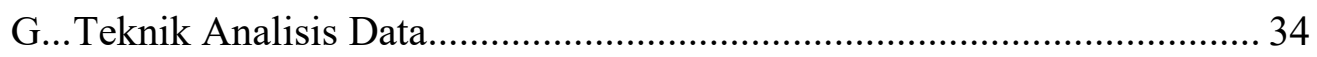

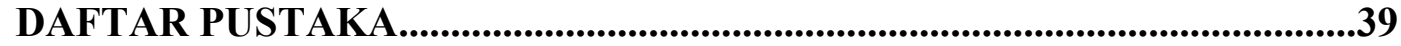




\section{BAB I}

\section{PENDAHULUAN}

\section{A. Latar Belakang Masalah}

Kemampuan berbahasa meliputi empat aspek keterampilan berbahasa. Keempat keterampilan tersebut yaitu, keterampilan mendengarkan, keterampilan berbicara, keterampilan membaca, dan keterampilan menulis. Menulis merupakan salah satu dari empat aspek keterampilan berbahasa. Semi (2007:14) mengatakan menulis merupakan suatu proses kreatif memindahkan gagasan ke dalam lambang-lambang tulisan. Keterampilan menulis tidak diperoleh secara otomatis, melainkan melalui latihan dan praktik yang banyak dan teratur (Tarigan, 2013:4). Secara harfiah, kegiatan menulis dapat diartikan sebagai kegiatan yang menggambarkan bahasa dengan lambang-lambang yang dapat dipahami. Hal tersebut sesuai dengan pendapat Tarigan (2008: 22) yang menyatakan bahwa "Menulis ialah menurunkan atau melukiskan lambang-lambang grafik yang menggambarkan suatu bahasa yang dipahami oleh seseorang sehingga orang-orang lain dapat membaca lambang-lambang grafik tersebut kalau mereka memahami bahasa dan gambaran grafik tersebut”.

Menulis merupakan salah satu keterampilan berbahasa yang penting untuk dikuasai siswa (Mantasiah et all, 2017; Qalbi et all, 2017). Oleh karena itu, keterampilan menulis juga harus dilatih secara intensif. Dalam Kamus Besar Bahasa Indonesia (KBBI) "Menulis berarti melahirkan pikiran atau perasaan dengan tulisan". Menulis yang baik adalah menulis yang dapat dipahami oleh orang lain. Menulis akan membuat siswa lebih kreatif dalam mengekspresikan dirinya sehingga kegiatan siswa lebih positif. Selain itu menulis juga bisa menjadi sarana hiburan bagi siswa, karena dengan menulis siswa mempunyai kesibukan. Hal itu sejalan dengan pendapat Nurjamal, dkk., (2011: 69) menyatakan bahwa menulis merupakan sebuah proses kreatif menuangkan gagasan dalam bentuk bahasa tulis untuk tujuan misalnya, memberi tahu, meyakinkan, menghibur. Menulis merupakan keterampilan bahasa yang tidak hanya membutuhkan keterampilan saja melainkan juga dengan pengetahuan dan kecerdasan berpikir. Untuk menghasilkan sebuah tulisan seseorang perlu mengetahui dan mendalami benar apa yang dituliskan tersebut sehingga tulisan yang dihasilkan tidak hanya sebagai sebuah tulisan kosong melainkan tulisan memiliki kualitas. 
Hal ini sejalan dengan pendapat Rosidi (2009:3) menyatakan bahwa kegiatan menulis dapat membantu siswa berlatih berpikir, mengungkapkan gagasan, dan memecahkan masalah. Melalui siswa akan berpikir dan mampu menuangkan idenya kedalam sebuah tulisan. Di sekolah, keterampilan menulis diajarkan dengan tujuan agar siswa mampu menulis dan menghasilkan suatu karya dalam bentuk tulisan. Keterampilan menulis memiliki berbagai jenis, salah satunya adalah menulis teks. Sejalan dengan itu, tuntutan kurikulum 2013 pada kelas VII SMP adalah mampu menulis teks deskripsi.

Teks deskripsi kini menjadi salah satu teks yang menjadi pusat fokus siswa sebagai tuntutan kurikulum 2013. Teks deskripsi merupakan bentuk wacana yang berusaha menyajikan suatu objek sedemikian rupa sehingga objek itu seolah-olah ada di depan pembaca, seakan-akan pembaca melihat sendiri objek itu (Alwi, dkk, 2002:97). Pengertian deskripsi dalam Kamus Bahasa Indonesia (Tim Penyusun Kamus Pusat Bahasa, 2008: 347) yaitu pemaparan dengan kata-kata secara jelas dan terperinci. Jadi deskripsi memaparkan (menunjukkan atau menggambarkan) sesuatu dengan kata-kata secara jelas dan terperinci sesuai dengan apa adanya. Hakim (1993) mengungkapkan bahwa teks deskripsi adalah lukisan atau hasil melukiskan atau menggambarkan sesuatu berdasarkan keadaan yang sebenarnya.

Syamsuddin, dkk (2007:81) menyatakan bahwa paragraf deskripsi bertujuan menggambarkan suatu benda, tempat, keadaan, atau perististiwa tertentu dengan kata-kata. Sejalan dengan pendapat Syamsudin, Slamet (2008: 103), mengungkapkan bahwa deskripsi adalah wacana yang melukiskan atau menggambarkan sesuatu berdasarkan kesan-kesan dari pengamatan, pengalaman, dan perasaan penulisnya. Tulisan deskripsi yang berhasil, dapat membawa pembaca untuk melihat, mendengar, merasakan atau mengalami langsung objek tersebut (Andayani, 2009: 36). Keterampilan menulis teks deskripsi memang menjadi satu keterampilan berbahasa yang sulit untuk dikuasai. Hal ini disebabkan adanya dua unsur yang harus dikuasai oleh penulis, yaitu unsur bahasa, seperti ejaan, stuktur kalimat, kohesi, dan koherensi, serta unsur non bahasa yang dijadikan ide atau gagasan dalam sebuah tulisan yang meliputi pengetahuan dan pangalaman penulis. Penguasaan keterampilan menulis teks deskripsi masih kurang optimal,terutama dalam unsur kebahasaan seperti ejaan dan struktur kalimat. Hal ini disebabkan oleh beberapa faktor baik faktor internal maupun eksternal. Faktor internal yang mempengaruhi kurang optimalnya keterampilan menulis teks deskripsi, yaitu, 1) siswa masih 
merasa bingung menuangkan ide pada saat akan memulai menulis, 2) siswa merasa sulit untuk memilih kata yang tepat, dan 3) siswa masih merasa kesulitan dalam menulis teks deskripsi sesuai dengan struktur dan kaidah kebahasaan.

Penyebab lain rendahnya keterampilan menulis deskripsi siswa adalah penguasaan kosakata siswa. Kosakata sebagai salah satu unsur bahasa memegang peranan penting dalam kegiatan menulis termasuk menulis teks deskripsi. Penguasan kosakata dan struktur kalimat bahasa Indonesia sangat penting dalam penguasaan keterampilan berbahasa, khususnya menulis. Abdul Chaer (2011: 131) menyatakan kosakata Bahasa Indonesia adalah semua kata yang terdapat dalam bahasa Indonesia. Tarigan (2015:2) menjelaskan bahwa kualitas keterampilan berbahasa yang dimiliki seseorang bergantung pada kuantitas dan kualitas kosakata yang dimilikinya. Tanpa penguasaan kosakata yang baik maka tujuan pembelajaran bahasa Indonesia tidak bisa tercapai, karena semakin efektif penguasaan kosakata maka semakin terampil pula berbahasa. Dalam Kamus Besar Bahasa Indonesia (Dekdikbud, 1996: 527), kosakata diartikan sebagai perbendaharaan kata. Kata-kata dalam suatu bahasa yang digunakan oleh seseorang dalam kegiatan menulis dan berbicara.

Menurut Munirah \& Hardian (2016 78-87) kosakata memegang fungsi dan peranan yang sangat penting dalam keterampilan berbahasa. Kosakata dapat menambah ilmu bahasa seseorang sehingga pengetahuan yang dimiliki semakin luas. Tarigan (2011:3) menjelaskan bahwa kosakata ialah kata-kata yang tidak mudah berubah atau sedikit sekali kemungkinannya dikutip dari bahasa lain. Sedangkan menurut Hiebert dan Kamil (2005:3) mengatakan "Generally, vocabulary ist the knowledge of meanings of words" dalam artian adalah kosakata dapat didefenisikan sebagai ilmu pengetahuan tentang arti kata. Adiwimarta (dalam Usman, dkk, 1979:2) mendefinisikan kosakata sebagai berikut. (1) semua kata yang terdapat dalam suatu bahasa, (2) kata-kata yang dikuasai seseorang atau kata-kata yang dipakai oleh segolongan orang dari lingkungan yang sama, (3) kata-kata yang dipakai dalam satu bidang ilmu pengetahuan, (4) seluruh morfem yang ada dalam suatu bahasa, dan (5) daftar sejumlah kata dan frase suatu bahasa yang disusun secara alfabetis disertai batasan dan keterangannya. Pengusaan kosa kata yang baik akan memberi dampak pada wawasan dan pengetahuan kosakata yang luas sehingga diharapkan seseorang dapat menyusun kalimat secara lebih baik. Berdasarkan permasalahan di 
atas, peneliti mengajukan judul penelitian "Korelasi Penguasaan kosa Kata dengan Keterampilan Menulis Teks Deskripsi Siswa Kelas VII di SMP Negeri 2 Kecamatan Gunung Omeh”.

\section{B. Identifikasi Masalah}

Berdasarkan latar belakang masalah dalam penelitian ini, identifikasi masalah dalam penelitian ini, yaitu (1) rendahnya kamampuan siswa dalam menulis teks deskripsi (2) siswa kesulitan dalam menuangkan ide atau gagasannya ke dalam bentuk tulisan, karena kurangnya kosakata khusunya kosakata dalam menulis teks deskripsi. (3) pada umumnya siswa belum memahami struktur teks deskripsi, (4) siswa masih kesulitan menulis teks deskripsi sesuai dengan struktur dan kaidah kebahasaan, (5) siswa belum mampu memilih kosa kata yang tepat dalam membuat teks deskripsi (6) kurangnya minat siswa untuk menulis karena sulit mengembangkan kata menjadi sebuah kalimat.

\section{Batasan Masalah}

Berdasarkan identifikasi masalah tersebut, pembatasan masalah pada penelitian ini dibatasi sebagai berikut. Pertama, penelitian ini dibatasi pada penguasaan kosakata teks deskripsi siswa kelas VII di SMP Negeri 2 Kecamatan Gunung Omeh. Kedua, keterampilan menulis teks deskripsi siswa kelas VII di SMP Negeri 2 Kecamatan Gunung Omeh. Ketiga, korelasi penguasaan kosakata dengan keterampilan menulis teks deskripsi siswa kelas VII di SMP Negeri 2 Kecamatan Gunung Omeh.

\section{Perumusan Masalah}

Berdasarkan identifikasi masalah dan bataasan masalah, rumusan masalah dalam penelitian ini adalah sebagai berikut. Pertama, bagaimanakah penguasaan kosakata keterampilan menulis teks deskripsi siswa kelas VII di SMP Negeri 2 Kecamatan Gunung Omeh? Kedua, bagaimanakah keterampilan menulis teks deskripsi siswa kelas VII di SMP Negeri 2 Kecamatan Gunung Omeh? Ketiga, bagaimanakah korelasi penguasaan kosa kata dengan keterampilan menulis teks deskripsi siswa kelas VII di SMP Negeri 2 Kecamatan Gunung Omeh?

\section{E. Tujuan Penelitian}

Berdasarkan rumusan masalah di atas, terdapat tiga tujuan dalam penelitian ini. Pertama, mendeskripsikan penguasaan kosakata keterampilan menulis teks deskripsi siswa kelas VII di 
SMP Negeri 2 Kecamatan Gunung Omeh. Kedua, mendeskripsikan keterampilan menulis teks deskripsi siswa kelas VII di SMP Negeri 2 Kecamatan Gunung Omeh. Ketiga, menganalisis korelasi penguasaan kosa kata dengan keterampilan menulis teks deskripsi siswa kelas VII di SMP Negeri 2 Kecamatan Gunung Omeh.

\section{F. Manfaat Penelitian}

Berdasarkan tujuan penelitian yang disampaikan, penelitian ini diharapkan dapat memberikan manfaat baik secara teoritis maupun praktis. Secara teoritis, penelitian ini diharapkan dapat bermanfaat untuk menambah wawasan dan ilmu pengetahuan di bidang menulis, khususnya menulis teks deskripsi. Secara praktis, penelitian ini dapat bermanfaat bagi guru Bahasa Indonesia, siswa, bagi peneliti sendiri maupun peneliti lain. Pertama, bagi guru Bahasa Indonesia khususnya di SMP Negeri 2 Kecamatan Gunung Omeh dugunakan sebagai referensi dalam pelaksanaan pembelajaran keterampilan menullis teks deskripsi. Kedua, bagi siswa SMP Negeri 2 Kecamatan Gunung Omeh, penelitian ini dapat memberikan manfaat agar siswa mengetahui kemampuan mereka dalam menguasai kosakata dalam menulis teks deskripsi, sehingga mereka dapat mengukur kemampuannya. Ketiga, bagi peneliti sendiri untuk menammbah wawasan dan pengetahuan dalam pembelajaran menulis teks deskripsi. Keempat, bagi peneliti lain digunakan sebagai referensi dan pembanding untuk melakukan penelitian selanjutnya.

\section{G. Defenisi Operasional}

Di dalam penelitian ini digunakan tiga defenisi operasional antara lain, (1) kosa kata (2) teks deskripsi, dan (3) korelasi.

\section{Kosakata}

Abdul Chaer (2011: 131) menyatakan kosakata Bahasa Indonesia adalah semua kata yang terdapat dalam bahasa Indonesia. Dalam Kamus Besar Bahasa Indonesia (Dekdikbud, 1996: 527), kosakata diartikan sebagai perbendaharaan kata. Kata-kata dalam suatu bahasa yang digunakan oleh seseorang dalam kegiatan menulis dan berbicara. Menurut Munirah \& Hardian (2016 78-87) kosakata memegang fungsi dan peranan yang sangat penting dalam keterampilan berbahasa. Kosakata dapat menambah ilmu bahasa seseorang sehingga pengetahuan yang dimiliki semakin luas. Tarigan (2011:3) menjelaskan bahwa kosakata ialah kata-kata yang tidak mudah berubah 
atau sedikit sekali kemungkinannya dikutip dari bahasa lain. Sedangkan menurut Hiebert dan Kamil (2005:3) mengatakan "Generally, vocabulary ist the knowledge of meanings of words" dalam artian adalah kosakata dapat didefenisikan sebagai ilmu pengetahuan tentang arti kata.

\section{Teks Deskripsi}

Teks deskripsi merupakan bentuk wacana yang berusaha menyajikan suatu objek sedemikian rupa sehingga objek itu seolah-olah ada di depan pembaca, seakan-akan pembaca melihat sendiri objek itu (Alwi, dkk, 2002:97). Pengertian deskripsi dalam Kamus Bahasa Indonesia (Tim Penyusun Kamus Pusat Bahasa, 2008: 347) yaitu pemaparan dengan kata-kata secara jelas dan terperinci. Jadi deskripsi memaparkan (menunjukkan atau menggambarkan) sesuatu dengan kata-kata secara jelas dan terperinci sesuai dengan apa adanya. Hakim (1993) mengungkapkan bahwa teks deskripsi adalah lukisan atau hasil melukiskan atau menggambarkan sesuatu berdasarkan keadaan yang sebenarnya.

Syamsuddin, dkk (2007:81) menyatakan bahwa paragraf deskripsi bertujuan menggambarkan suatu benda, tempat, keadaan, atau perististiwa tertentu dengan kata-kata. Sejalan dengan pendapat Syamsudin, Slamet (2008: 103), mengungkapkan bahwa deskripsi

adalah wacana yang melukiskan atau menggambarkan sesuatu berdasarkan kesan-kesan dari pengamatan, pengalaman, dan perasaan penulisnya.

\section{Korelasi}

Pengusaan kosakata yang baik akan memberi dampak pada wawasan dan pengetahuan kosakata yang luas sehingga diharapkan seseorang dapat menyusun kalimat secara lebih baik dalam menulis teks deskripsi. 


\section{BAB II}

\section{KAJIAN PUSTAKA}

\section{A. Kajian Teori}

\section{Keterampilan Menulis Teks Deskripsi}

\section{a. Pengertian Teks Deskripsi}

Teks deskripsi merupakan salah satu teks yang harus dikuasai oleh siswa. Deskripsi berasal dari bahasa Inggris description yang berarti melukiskan". Melukiskan adalah memaparkan suatu objek atau peristiwa dengan sedemikian rupa sehingga objek itu seolah-olah dapat dilihat dan dirasakan oleh pembaca. Semi (2007:66) menyatakan bahwa deskripsi adalah tulisan yang tujuannya memberikan rincian atau detail tentang objek, sehingga dapat memberi pengaruh pada emosi dan menciptakan imajinasi pembaca atau pendengar, pembaca seolah melihat, mendengar, atau merasakan langsung objek yang dideskripsikan penulis.

Menurut Harsiati, dkk. (2016:7-8), teks deskripsi adalah sebuah teks yang menggambarkan objek dengan cara merinci objek secara subjektif atau melukiskan kondisi objek dari sudut pandang penulis. Teks deskripsi bertujuan untu menggambarkan atau melukiskan secara rinci dan penggambaran suatu objek, suasana, dan perasaan secara konkret, sehingga pembaca seakan-akan melihat, mendengarkan, dan mengalami apa yang dideskripsikan. Objek yang dibicarakan pada teks deskripsi bersifat khusus (objek tertentu yang kemungkinan berbeda dengan objek lain). Objek yang dideskripsikan bersifat pendapat personal. Isi teks deskripsi diperinci menjadi perincian bagian-bagian objek. Isi teks deskripsi menggambarkan secara konkret. Dengan demikian, teks deskripsi banyak menggunakan kata khusus. Isi teks deskripsi bersifat personal dengan kandungan emosi sehingga menggunakan kata-kata dengan menggunakan emosi kuat.

Kosasih (2006: 26) berpendapat bahwa teks deskripsi adalah karangan yang menggambarkan suatu objek dengan tujuan agar pembaca merasa seolah-olah melihat sendiri objek yang digambarkan itu, sedangkan menurut Mahsun (2014: 28), teks deskripsi adalah teks yang memiliki tujuan sosial untuk menggambarkan suatu objek atau benda secara individual berdasarkan ciri fisiknya. Teks deskriptif juga merupakan tulisan yang menggambarkan atau 
melukiskan sesuatu yang akan diungkapkan penulis, sehingga pembaca atau yang mendengar seolah-olah melihat sendiri objek yang telah dibicarakan, meskipun pembaca atau pendengar belum pernah menyaksikan sendiri.

Berdasarkan pendapat para ahli di atas dapat disimpulkan bahwa teks deskripsi adalah teks yang berguna untuk menggambarkan suatu objek baik berupa benda, tempat, atau peristiwa, yang seolah-olah pembaca dapat melihat, mendengar, dan mengalami apa yang dideskripsikan di dalam teks tersebut.

\section{b. Struktur Teks Deskripsi}

Menurut Harsiati, dkk. (2016:20), struktur teks deskripsi dalam pembelajaran bahasa Indonesia ada tiga. Struktur teks deskripsi terdiri atas identifikasi, deskripsi bagian, dan simpulan. Ketiga struktur teks deskripsi tersebut adalah sebagai berikut.

Pertama, identifikasi. Identifikasi berisi nama objek yang dideskripsikan, lokasi sejarah lahirnya, makna nama, dan pernyataan umum tentang objek. Kedua, deskripsi bagian. Deskripsi bagian merupakan perincian bagian objek berdasarkan tanggapan subjektif penulis. Perincian dapat berisi apa yang dilihat (bagian-bagian, komposisi warna, seperti apa objek yang dilihat menurut kesan penulis). Perincian juga dapat berisi apa yang dirasakan penulis dengan mengamati objek. Ketiga, Simpulan. Simpulan merupakan tanggapan terhadap objek. Simpulan berisi kesan terhadap hal yang dideskripsikan.

Mahsun (2014:29) mengemukakan tiga struktur teks deskripsi, yaitu (1) judul. Dalam judul, dituliskan beberapa kata yang mewakili isi dari teks deskripsi dan objek yang dideskripsikan. (2) Pernyataan umum, yaitu menjelaskan tentang definisi atau identitas objek yang dideskripsikan. (3) Uraian bagian-bagian. Pada bagian ini, dijelaskan tentang pengklasifikasian objek yang dideskripsikan. Pengklasifikasian dijelaskan secara lebih rinci dengan memberikan gambaran - gambaran yang jelas.

Berdasararkan pendapat di atas, dapat disimpulkan bahwa struktur teks deskripsi ada tiga, yaitu identifikasi, yang berisi tentang pernyataan umum tentang objek, seperti nama, sejarah, lokasi, dan identitas objek, deskripsi bagian, berisi perincian tentang bagian-bagian objek, dan simpulan berisi tentang tanggapan atau kesan penulis terhadap objek yang dideskripsikan. 


\section{c. Isi Teks Deskripsi}

Menurut Harsiati, dkk. (2016:8) ciri isi teks deskripsi sebagai berikut :

1) Isi teks deskripsi diperinci menjadi perincian bagian-bagian objek.

2) Isi teks deskripsi menggambarkan secara konkret (menggambarkan wisata yang indah dan dikonkretkan indahnya seperti apa, menggambarkan ibu yang baik akan dikonkretka baiknya seperti apa). Dengan demikian, teks deskripsi banyak menggunakan kata khusus (warna dikhususkan pada kata hijau, merah, kuning, dan lain-lain).

3) Isi teks deskripsi bersifat personal dengan kandungan emosi sehingga menggunakan kata-kata dengan emosi kuat (ombak menggempur, kemolekan pantai, 1buku yang tangguh).

Selanjutnya, Wahono, dkk. (2013:50) menyatakan bahwa isi teks deskripsi menggambarkan suatu objek atau benda secara spesifik atau rinci kepada pembaca. Teks deskripsi paling sering digunakan dalam visualisasi sastra, khususnya prosa. Hal ini tercermin dari suasana penggambaran latar atau tokoh dalam sebuah prosa yang menyebabkan pembaca seolah bisa melihat langsung tokoh dalam sebuah prosa yang menyebabkan pembaca seolah bisa melihat langsung tokoh atau latar yang dideskripsikan oleh pengarangnya. Sejalan dengan itu, Mahsun (2014:28) menyatakan isi dari teks deskripsi adalah gambaran yang dipaparkan dalam teks harus spesifik menjadi ciri keberadaan objek yang digambarkan.

\section{d. Ciri Umum Teks Deskripsi}

Mulyadi (2014:58) mengungkapkan bahwa ada empat ciri-ciri yang terdapat dalam teks dekripsi. Keempat ciri tersebut adalah sebagai berikut. Pertama, menggambarkan atau melukiskan suatu benda, tempat, atau suasana tertentu. Kedua, penggambaran dilakukan dengan melibatkan pancaindera (pendengaran, penglihatan, penciuman, pengecapan, dan perabaan). Ketiga, bertujuan agar pembaca seolah-olah melihat atau merasakan sendiri objek yang dideskripsikan. Keempat, menjelaskan ciri-ciri objek seperti warna, ukuran, bentuk, dan keadaan suatu objek secara terperinci.

Senada dengan hal itu, Harsiati (2013:29) menyatakan bahwa sebuah teks deskripsi memiliki ciri-ciri seperti berikut. Pertama, menyajikan keadaan waktu, peristiwa, tempat, benda, dan orang. Kedua, menimbulkan kesan-kesan tertent kepada pembaca. Ketiga, memungkinkan 
terjadinya imajinasi bagi pembacanya. Keempat, banyak menggunakan kata atau frasa yang bermakna keadaan atau sifat.

Berdasarkan pendapat para ahli tersebut dapat disimpulkan bahwa ciri-ciri umum teks deskripsikan adalah pertama, menggambarkan atau melukiskan sesuatu. Kedua, penggambaran dilakukan dengan menggunakan pancaindera. Ketiga, bertujuan agar pembaca seolah-olah melihat atau merasakan secara individu objek yang dideskripsikan. Keempat, menjelaskan ciriciri objek seperti warna, ukuran, bentuk, dan keadaan suatu objek secara terperinci.

\section{e. Penggunaan Bahasa Teks Deskripsi}

Harsiati, dkk. (2016:21-27) menerangkan bahwa dalam pembelajaran teks deskripsi ada beberapa penggunaan bahasa yang akan dipelajari. Penggunaan bahasa tersebut, yaitu (1) penggunaan kalimat perincian, (2) penggunaan kalimat cerapan panca indra, (3) penggunaan kata berimbuhan, (4) penggunaan sinonim, (5) penggunaan kata depan, (6) penggunaan kata khusus, (7) kalimat bermajas, dan (8) penggunaan pilihan kata yang bervariasi.

\section{1) Penggunaan Kalimat Perincian}

Harsiati, dkk. (2016:21) menjelaskan bahwa kalimat perincian adalah kalimat yang isinya tentang detail atau penjabaran suatu objek yang dimaksud. Contoh kalimat, Kakek orang yang sangat baik. Perincian kalimat tersebut bisa dijelaskan menjadi, Dia selalu menolong semua orang. Perincian kata baik bisa menjadi, suka menolong, tutur kata lemah lembut, dermawan, dan sebagainya.

\section{2) Penggunaan Kalimat Cerapan Panca Indra}

Harsiati, dkk. (2016:22) menerangkan bahwa teks deskripsi menggunakan kalimat yang seolah-olah dapat dilihat, didengar, dan dirasakan. Contoh kalimat seolah-olah pembaca melihat, air jernih dengan buih-buih kecil. Contoh kalimat seolah-olah pembaca mendengar, debur ombak pantai terdengar berirama. Contoh kalimat seolah-olah pembaca merasakan, udara terasa sangat segar.

3) Penggunaan Kata Berimbuhan

Harsiati, dkk. (2016:23) menyatakan bahwa penggunaan kata dengan kata dasar yang huruf pertamanya k, p, t, dan s akan luluh jika ditambahkan awalan. Contoh kata pesona yang 
diberi imbuhan meN (meN- + pesona) menjadi memesona karena huruf p luluh menjadi huruf $\mathrm{m}$ karena setelah awalan meN- diikuti oleh kata dasar yang diawali dengan hurufp. Selain itu, penggunaan kata berimbuhan seperti di- ditulis serangkai dengan kata yang mengikutinya. Dalam hal ini, di- berfungsi sebagai imbuhan pada kata kerja pasif.

\section{4) Penggunaan Sinonim}

Harsiati, dkk. (2016:24) menerangkan bahwa teks deskripsi menggunakan kata bersinonim agar tidak terjadi pengulangan kata-kata yang sama dalam pengindraan sebuah objek yang dapat menyebabkan teks deskripsi tersebut menjadi tidak menarik. Contoh kata indah bersinonim dengan kata elok, permai, dan molek.

Chaer (2012:297) menjelaskan bahwa sinonim adalah hubungan semantik yang menyatakan adanya kesamaan makna antar suku satuan ujaran dengan ujaran lain. Misalnya, antara kata betul dengan kata benar. Sedangkan Tarigan (2011:68) berpendapat bahwa sinonim kata adalah kata-kata yang mengandung arti pusat yang sama, tetapi berbeda nilai kata. Secara singkatnya, sinonim adalah kata-kata yang memiliki denotasi yang sama, tetapi berbeda dalam konotasi.

\section{5) Penggunaan Kata Depan (Preposisi)}

Kosasih, dkk. (2016:24) menjelaskan bahwa kata depan di sebagai kata depan jika diikuti dengan kata keterangan tempat, arah, posisi, atau letak. Sebagai kata depan, di ditulis terpisah dengan kata yang mengikutinya, seperti di pantai, disamping, dan di bagian barat.

\section{6) Penggunaan Kata Khusus}

Harsiati, dkk. (2016:25) menjelaskan bahwa kata khusus adalah kata yang ruang lingkup dan cakupan maknanya lebih sempit. Kata-kata yang termasuk dalam kata umum adalah hipernim. Selanjutnya, ada kata umum yang merupakan kata yang ruang lingkupnya luas dan mencakup banyak hal. Kata umum dan kata khusus sebenarnya sinonim, tetapi dengan makna yang 1lebih khusus. Contoh kata umum melihat, kata khususnya adalah menonton, menyaksikan, memandang, mengamati, dan memerhatikan.

7) Kalimat Bermajas 
Harsiati, dkk. (2016:26) menerangkan bahwa majas yang terdapat pada teks deskripsi adalah majas asosiasi dan majas personifikasi. Majas asosiasi adalah majas yang membandingkan sesuatu dengan keadaan lain karena adanya persamaan sifat, sedangkan majas personifikasi merupakan majas yang memberikan sifat manusia kepada benda mati.

Manaf (2010:125) membedakan majas menjadi dua macam. Pertama, majas persamaan atau simile, digunakan untuk membandingkan sesuatu dan sifatnya eksplisit. Dalam perbandingan eksplisit sesuatu yang dimaksudkan disamakan dengan sesuatu yang lain dengan menggunakan kata perumpamaan atau perbandingan secara eksplisit, misalnya seperti. Contoh majas perbandingan dengan menggunakan kata seperti yaitu, anaknya seperti bulu kucing. Kedua, majas personifikasi, digunakan untuk memberikan sifat-sifat yang dimiliki manusia atau perilaku yang lazim dilakukan manusia kepada benda. Dengan kata lain, majas personifikasi adalah gaya bahasa yang memperlakukan benda-benda seolah-olah bersifat dan berperilaku seperti manusia. Contohnya, matahari berjalan mendahului bulan, tetapi mereka tidak pernah bertikai.

\section{8) Penggunaan Pilihan Kata yang Bervariasi}

Harsiati, dkk. (2016:27) menjelaskan bahwa teks deskripsi menggunakan kosakata secara segar dengan variasi kata yang luas. Contohnya seperti kata mengagumkan, mempesona, menakjubkan, dan memukau. Penggunaan kata bervariasi ini berguna agar pembaca tidak bosan dengan kata-kata yang sama dalam teks deskripsi.

Berdasarkan pendapat di atas, dapat disimpulkan bahwa ada delapan penggunaan bahasa teks deskripsi, yaitu penggunaan kalimat perincian, kata berimbuhan, penggunaan kalimat cerapan panca indra, penggunaan kata berimbuhan, penggunaan sinonim, penggunaan kata depan, penggunaan kata khusus, kalimat bermajas, dan penggunaan pilihan kata bervariasi. Penggunaan bahasa dalam teks deskripsi berfungsi untuk mencapai tujuan dari teks tersebut dan yang lebih penting lagi adalah mengikuti kaidah bahasa yang baik dan benar.

\section{f. Langkah-langkah Menulis Teks Deskripsi}

Harsiati, dkk. (2016:37-39) menyatakan bahwa ada enam langkah menulis teks deskripsi, yaitu sebagai berikut. Pertama, tentukan subjek yang akan dideskripsikan, dan buat judul. Judul 
teks tanggapan deskriptif berisi objek yang akan dideskripsikan berdaasarkan tanggapan personal penulis. Kedua, buatlah kerangka bagian-bagian yang akan dideskripsikan. Ketiga, carilah data dari subjek yang ditulis. Data dicari dengan cara mengamati subjck yang akan dideskripsikan. Keempat, tatalah kalimat-kalimat menjadi paragraf pembuka teks tanggapan deskriptif atau identifikasi, paragraf deskripsi bagian 1, deskripsi bagian 2, deskripsi bagian 3, dan paragraf simpulan. Kelima, perincilah objek atau suasana yang dideskripsikan dengan menggunakan kata dan kalimat yang merangsang panca indera. Pembaca yang tidak menerima langsung seolah-olah melihat, mendengar, dan merasakan apa yang dideskripsikan. Keenam, gunakan variasi kata secara menarik.

Selanjutnya, Semi (2007:72-78) menjelaskan dua langkah dalam menulis teks deskripsi. Pertama, pilih detail secara teliti. Pilihlah detail yang sangat baik untuk dipaparkan. Misalnya, mendeskripsikan tentang keindahan suatu objek wisata. Hal-hal yang perlu ditampilkan adalah hal yang mendukung keindahan objek wisata tersebut, sedangkan kelemahan dari objek wisata tersebut tidak perlu ditampilkan karena menganggu tujuan tulisan. Kedua, gunakan pilihan kata yang tepat. Untuk mendukung apa yang diamati atau dirasakan penulis sehingga dapat diamati dan dirasakan oleh pembaca harus menggunakan ungkapan atau kata yang spesifik. Artinya, kata yang secara khusus dipakai untuk suatu benda atau nama tertentu. Janganlah menggunakan istilah yang sangat umum, karena istilah umum tidak akan memancing kesan yang khas.

Berdasarkan penjabaran tersebut, dapat disimpulkan bahwa langkah - langkah menulis teks deskripsi yaitu menentukan subjek yang akan dideskripsikan atau yang sangat baik untuk dipaparkan, membuat kerangka, mencari data dari subjek yang ditulis, menata kalimat menjadi teks deskripsi, merinci objek, dan menggunakan kata yang spesifik, pilihan kata yang tepat, dan variasi kata yang menarik. 


\section{g. Contoh Teks Deskripsi}

\section{Keindahan Alam Indonesia}

\section{Deskripsi umum}

Indonesia adalah negara dengan kekayaan alam yang melimpah ruah dari Sabang hingga Merauke. Keindahan alam Indonesia memang dinilai tak ada yang mampu menandingi di negara mana pun di dunia.

\section{Deskripsi Bagian}

Hampir semua pesona alam terdapat di Indonesia, mulai daratan hingga laut. Oleh sebab itu, tidak heran banyak wisatawan asing yang rela datang jauhjauh ke Indonesia untuk menikmati keindahan alam bumi pertiwi.

Selain keindahan alam yang disajikan, ternyata di dalam keindahan tersebut terdapat banyak hal tersembunyi yang jarang diketahui, seperti flora dan fauna yang sangat langka dan eksotis. Alam Indonesia yang paling tersohor di mata dunia adalah keindahan pantainya yang terbentang dari barat hingga ke timur.

Banyaknya pulau yang ada di Indonesia membuat kekayaan laut dan pantai makin berwarna. Selain pantai, keindahan dunia bawah laut juga menjadi incaran para wisatawan untuk masuk ke dalamnya dan ikut menikmati kehidupan bawah laut di Indonesia.

Daerah yang memiliki keindahan pantai yang menakjubkan di Indonesia yang paling tersohor adalah Manado, Bali, dan Raja Ampat. Tidak hanya keindahan pantai, Indonesia merupakan negara dengan cangkupan hutan terbesar di Dunia. Oleh karena itu Indonesia disebut sebagai paru-paru dunia, sebab 1/3 hutan di dunia terdapat di Indonesia.

\section{Penutup}

Keindahan hutan di Indonesia memang tak perlu diragukan lagi, sebab memang hijau hamparan pohon membuat mata seakan terhipnotis. Selain itu, hewan dan tumbuhan endemik banyak yang menjadi buruan wisatawan yang hanya untuk berfoto untuk mengabadikan momen tersebut. 


\section{Penguasaan Kosakata}

\section{a. Pengertian Kosakata}

Chaer (2007:6-8) menyatakan bahwa kosakata adalah sebagai berikut.

Pertama, semua kata yang terdapat dalam suatu bahasa. Kedua, kata-kata yang dikuasai oleh seseorang atau sekelompok orang dari lingkungan yang sama. Ketiga, kata-kata atau istilah yang digunakan dalam satu bidang kegiatan atau ilmu pengetahuan. Keempat, sejumlah kata dari suatu bahasa yang disusun secara alfabetis beserta penjelasan maknanya, layaknya sebagai sebuah kamus. Kelima, semua morfem yang ada dalam suatu bahasa.

Menurut Kuncoro (2009:97), kosakata adalah keseluruhan kata yang berkenaan dengan suatu bahasa atau bidang tertentu yang ada di dalamnya. Kosakata adalah himpunan kata yang diketahui seseorang. Kosakata dalam bahasa Inggris disebut vocabulary, kosakata seseorang didefinisikan sebagai himpunan semua kata-kata yang dimengerti oleh orang tersebut atau semua kata-kata yang kemungkinan akan digunakan oleh orang tersebut untuk menyusun kalimat baru.

Djiwandono (2011: 126) menjelaskan bahwa kosakata diartikan sebagai perbendaharaan katakata dalam berbagai bentuk yang meliputi kata-kata lepas dengan atau tanpa imbuhan dan kata-kata yang merupakan gabungan dari kata-kata yang sama atau berbeda, masing-masing dengan artinya sendiri. Abdul Chaer (2011: 131) menyatakan kosakata Bahasa Indonesia adalah semua kata yang terdapat dalam bahasa Indonesia.

Menurut Kridalaksana (dalam Munirah dan Hardian, 2016:82), kosakata adalah (1) komponen bahasa yang memuat semua informasi tentang makna atau arti dan pemakaian kata dalam bahasa, (2) kekayaan kata yang dimiliki oleh Seseorang pembicara, penulis dari suatu bahasa. Selanjutnya, Citra (dalam Munirah dan Hardian, 2016:82) mengemukakan bahwa kosakata dapat diartikan Sebagai, (1) semua kata yang terdapat dalam satu bahasa, (2) kekayaan kata yang dimiliki oleh pembicara dan penulis, (3) kata yang dipakai dalam satu bidang ilmu pengetahuan, dan (4) daftar kata yang disusun seperti kamus yang disertai penjelasan singkat dan praktis. 
Berdasarkan pendapat para ahli tersebut, dapat disimpulkan bahwakosakata adalah perbendaharaan kata atau kekayaan kata yang dipakai dan keseluruhan kata yang dimiliki oleh suatu bahasa, baik yang diucapkan, didengar, ditulis, dan dibaca.

\section{b. Jenis - jenis Kosakata}

Pateda (1995:82-90) menyatakan bahwa jenias kosakata terdiri atas enaman jenis. Keenam jenis kosakata tesebut adalah: (1) kosakata dasar, (2) kosakata umum dan kosakata khusus, (3) kosakata abstrak dan kosakata konkret, (4) kosakata populer (5) kosakata asli dan koskaata populer, dan (6) kosakata menurut bidangnya. deskripsi keenam jenis tersebut sebagai berikut.

1) Kosakata Dasar (basic vocabulary)

Kosakata dasar bukan untuk digunakan dalam berkomunikasi, melainkan sengaja diusulkan agar memudahkan penelitian, yaitu untuk menentukan tingkat kekerabatan bahasa. Dengan kata lain, kosakata dasar biasa digunakan dalam bidang kompratif. Sarjana yang mengusulkan kosakata dasar adalah Morris Swadesh mengusulkan sebanyak 200 buah kosakata dasar. Kata-kata ini bersifat universal dan diperkirakan berdaya tahan 1000 tahun. Contoh dari kosakata dasar ini adalah air, angin, buah, bunga, kucing, dan mati.

2) Kosakata Umum dan Kosakata Khusus

Kosakata umum kata-kata umum yang digunakan oleh hampir seluruh masyarakat pemakai bahasa di daerah tertentu. Selain digunakan secara luas, kosakata umum selalu digunakan untuk komunikasi misalnya kata uang merupakan kosakata umum karena kosakata tersebut digunakan untuk komunikasi. Kata uang maknanya dipahami secara luas dan oleh masyarakat penutur bahasa Indonesia mengetahui acuan kata uang.

Menurut Keraf (2009: 90) bila sebuah kata mengacu kepada suatu hal atau kelompok yang luas bidang lungkupnya maka kata itu disebut kata umum. Kosakata khusus adalah katakata yang digunakan khusus dalam bidang ilmu, bidang kegiatan tertentu atau di lingkungan tertentu misalnya kata produksi merupakan contoh kata khusus yang digunakan dalam bidang ekonomi. Menurut Keraf (2009:90) kata-kata yang mengacu kepada pengarahan-pengarahan yang khusus dan kongkret maka kata-kata itu di sebut kata khusus. Karena kata yang khusus 
memperlihatkan perialian yang khusus atau kepada obyek yang khusus, maka kesesuaian akan lebih cepat diperoleh pembaca dan penulis. Kata sebagai satuan dari perbendaharaan kata sebuah bahasa mengandung dua aspek, yaitu bentuk atau ekspresi dan aspek isi makna. Bentuk adalah segi yang dapat dicerap dengan pancera indra, sedangkan segi isi atau makna adalah segi yang menimbulkan reaksi dalam pikiran pendengar dan peinbaca karena rangsangan aspek bentuk tadi Keraf (2009:25). Makna konotatif atau yang disebut sebagai makna kias merupakan perbendaharaan kata dari segi bentuk isi atau makna. Menurut Keraf (2009: 20), makna konotatif atau makna kias adalah suatu jenis makna di mana stimulus dan respons mnegandung ilai-nilai emosional. Misalnya kata mati, meinggal, wafat, gugur, mangkat, berpulang, cemberut, penakut, bangkrut, melirik, meluap, dan sebagainya.

Suatu jenis pengkhususan dalam memilih kata-kata yang tepat adalah penggunaan 1stilah-istilah yang menyatakan pengalaman-pengalaman yang dicerap pancaindria, yaitu cerapan indria penglihatan, pendengaran, peraba, perasa, dan penciuman ( Keraf. 2009:94). Katakata yang sering digunakan untuk menyatakan pencerap sebagai berikut:

a) Peraba merupakan alat indera untuk meraba, contohnya kata dingin, panas, lembab, basah, kering, kasap, kerut, halus rata, licin, gelenyar, geli, gelenyar, dan sebagainya.

b) Perasa merupakan alat indera untuk mengecap rasa, contohnya kata pedas, pahit, asam, gayau, asin, kelat.

c) Penciuman merupakan alat indera untuk mencium bau, contohnya kata asam, tajam, pedis, kohong, pesing, lapuk, apak, basi, anyir tengik, dan sebagainya.

d) Pendengaran merupakan alat indera untuk mendengar, contohnya kata dengung, deru, anyir, tengik, kicau, lengking, repet, menyui, desau, desir, berkerosok, bersenandung, berbisik, cebur, . merenyah, mcrengek, dan sebagainya.

e) Penglihatan merupakan alat indera untuk melihat, contohnya kata pijar, kabur, mengkilap, belang, merah, corak, keruh, cemong, hitam putih, pucat, pudar kejap, mewah, merah, menyolok, seri, marak, cahaya, becek, berlumpur, pucat. 
Berdasarkan penjelasan tersebut dapat disimpulkan bahwa kosakata umum dan kosakata khusus yang berkaitan dengan indikator teks cerita fantasi dalam bentukan ciri kebahasaan merupakan pembentukan dari indikator penguasaan kosakata.

3) Kosakata Abstrak dan Konkret

Kosakata abstrak adalah kata-kata acuannya hanya dapat dibayangkan. Untuk memahami kosakata yang bersifat abstrak, seseorang harus mengerti apa yang dimaksud, dapat mengidentifikasi cirinya, dan dapat menjelaskan kepada orang lain. Misalnya, hasutan dan gengsi. Kosakata konkret adalah kata-kata yang acuannya nyata. Misalnya, kata-kata seperti baju, buku, dan pena.

4) Kosakata Populer

Kosakata populer adalah kata-kata yang digunakan untuk berkomunikasi. Kosakata populer berbeda dengan kosakata umum terutama karena dilihat dari segi frekuensi pemakaian. Kosakata populer memiliki frekuensi pemakaian yang tinggi. Di antara sekian banyak kata yang bersifat umum, ada beberapa yang bersifat populer. Kata korupsi misalnya, merupakan kata populer untuk kegiatan mencuri di kalangan pegawai. Kata calo merupakan kosakata populer dalam bidang tidak resmi atau responden adalah kata kajian yang lazim digunakan dalam pengkajiannya (Pateda, 1995:86).

\section{5) Kosakata Asli dan Kosakata Serapan}

Menurut Pateda (1995:87), kosakata asli adalah kata-kata dalam bahasa tertentu bukan berasal dari bahasa lain. Kata-kata itu diciptakan oleh penutur bahasa yang bersangkutan dan telah digunakan turun-temurun. Dalam perkembangan pemakaian bahasa, kosakata asii itu kadang-kadang .berubah bentuk dan lafalnya. Kosakata bahasa Indonesia asli merupakan kosakata yang berasal dari bahasa Indoncsia, misalnya kata banbu dan orang hutan merupakan kosakata asli bahasa Indonesia. Kosakata serapan adalah kata-kata yang diserap dari bahasa lain (Pateda, 1995:89). Misalnya, kata energi dan reliabelitas merupakan contoh kosakata yang diserap dari bahasa asing.

6) Kosakata Menurut Bidangnya 
Manusia yang memiliki bahasa memanfaatkan bahasa tersebut untuk hidup dan kehidupan terkait dengan banyak bidang kehidupan. Melihat banyaknya bidang kehidupan dan yang melengkapi kehidupan manusia, tentu kita berusaha memahami makna kata yag terdapat dalam bidang tertentu agar kita dapat berkomunikasi dengan siapa saja. Kosakata menurut bidang - bidang tersebut dianataranya kosakata dalam bidang administrasi, lingkungan hidup, keagamaan, kehutanan, kesehatan, dan kesenian.

Berdasarkan uraian di atas, kosakata terdiri dari beberapa jenis yaitu, kosakata dasar, kosakata umum dan kosakata khusus, kosakata abstrak dan kosakata konkrit, kosakata pupuler, kosakata asli dan kosakata serapan, dan kosakata menurut bidangnya.

\section{c. Tujuan Pembelajaran Kosakata}

Tarigan (2008:1) menyatakan bahwa bahasa seseorang mencerminkan pikirannya. Semakin terampil seseorang berbahasa, semakin cerah dan jelas pula jalan pikirannya. Artinya, terdapat hubungan antara keterampilan berbahasa seseorang dengan kemampuan berpikirnya. Kualitas keterampilan berbahasa seseorang bergantung kepada kuantitas dan kualitas kosakatanya. Semakin kaya kosakata yang dikuasai oleh seseorang, maka semakin bagus keterampilan berbahasanya. Jadi, tujuan pengajaran kosakata adalah untuk meningkatkan keterampilan berbahasa dan kemampuan berpikir siswa.

Berdasarkan uraian tersebut, dapat disimpulkan bahwa pengajaran kosakata memiliki tujuan meningkatkan penguasaan kosakata siswa; meningkatkan perkembangan konseptuai, meningkatkan keterampilan mental siswa dalam berbahasa; mempertajam daya pikir kritis; dan memperluas cakrawala siswa.

\section{d. Pengembangan Kosakata}

Tarigan (1993:78) menjelaskan bahwa penguasaan kosakata adalah kegiatan menguasai atau keterampilan memahami dan menggunakan kata-kata yang terdapat dalam suatu bahasa, baik bahasa lisan maupun tulisan. Penguasaan kosakata sangat diperiukan, semakin banyak kosakata yang dimliki seseorang semakin mudah pula ia menyampaikan dan menerima informasi. Bahkan kosakata dapat dipakai sebagai ukuran kepandaian seseorang. Berikut diuraikan cara memperluas penguasaan kosakata yakni dengan menentukan sinonim, antonim, makna kata, dan pilihan kata. 


\section{Pengembangan Penguasaan Kosakata dengan Cara Menentukan Sinonim}

Tarigan (1993:78) menyatakan bahwa sinonim adalah penggantian kata - kata. Sinonim memberikan kita kesempatan untuk mengekspresikan gagasan yang sama dalam berbagai cara, walaupun konteks, latar, suasana hati, dan nada si pembicara sebagai suatu keseluruhan dapat saja mengendalikan pemilihan. Sinonim yang akan dipergunakan walaupun telaah daftar sinonim dapat menolong para siswa untuk mengklasifikasikan konsep-konsep umum (seperti: kayamiskin, jauh-dekat, siang-malam), tetapi nilainya yang lebih tinggi adalah dalam pengembangan kemampuan para siswa membuat pembedaan-pembedaan yang tajam antar sinonim yang satu dengan yang lainnya. Menelaah mengenai sinonim merupakan pendekatan yang sangat baik untuk meningkatkan penguasaan kosakata (Manaf, 2008:95). Sinonim merupakan persamaan kata yang terdapat dalam satu bahasa. Contoh kata ibu, emak, mama adalah mengacu kepada objek atau konsep yang sama yaitu orang tua perempuan". Walaupun makna satuan bahasa yang bersinonim itu sama, namun bentuk-bentuk yang bersinonim itu tetap memiliki nuansa perbedaan baik perbedaan yang halus maupun perbedaan yang tipis.

Berdasarkan uraian tersebut, dapat disimpulkan bahwa sinonim adalah sekelompok kata yang berbentuk nama namun mengandung makna yang sama atau sekelompok butir leksikal yang mengandung kemiripan makna antara yang satu dengan yang lainnya. Latihan mengenai Sinonim, diharapkan dapat meningkatkan perbendaharaan dan penguasaan kosakata sehingga siswa terampil dalam menulis.

\section{Pengembangan Penguasaan Kosakata dengan Cara Menentukan Antonim}

Cara efektif untuk meningkatkan keterampilan kosakata para siswa adalah melalui antonim karena tidak ada dua sinonim yang benar-benar sama maknanya, maka sedikit sekali antonim yang benar-benar merupakan lawan dari kata-kata lain (Tarigan, 1993:85). Tetapi seperti juga halnya sinonim, maka kita dapat pula mengklasifikasikan istilah-istilah tertentu sebagai lawan makna. Selain itu menolong siswa untuk mempelajari konsep negatifisme dalam bahasa, konsep yang pertama kali ditemui dalanı penggunaan konjungsi atau kata sambung tetapi, akan tetapi, dan lain-lain. Oleh karena itu, mengklasifikasikan antonim-antonim jelas membantu siswa berpikir dalam istilah-istilah yang membedakan atau konsep-konsep yang bertentangan. 
Manaf (2008:102) menyatakan bahwa antonim adalah hubungan pertentangan makna atau istilah kata yang satu dengan makna kata lain yang mengandung hubungan perbedaan tingkat dengan kata contoh, kata ayah dengan ibu, hidup dengan mati, penjual dan pembeli. Mempunyai hubungan oposisi karena kata-kata itu mempunyai makna yang bertentangan atau berlawanan dan tidak mengandung gradasi. Contoh, kata ayah "orang tua laki-laki'" berlawanan makna dengan kata ibu "orang tua perempuan.

Berdasarkan uraian tersebut, dapat disimpulkan bahwa antonim adalah hubungan pertentangan makna atau kebalikan makna kata yang satu dengan yang lain yang mengandung perbedaan tingkat. Menentukan antonim dapat membantu Siswa dalam pengembangan kosakata karena dengan menentukan antonim siswa terbantu dengan latihan-latihan yang diberikan, sehingga kosakata yang dimiliki oleh siswa kian bertambah. Hal tersebut dapat membantu siswa menngembangkan ide saat menulis.

\section{Pengembangan Penguasaan Kosakata dengan Cara Menentukan Makna dari Sebuah Kata}

Manaf (2008:73) menyatakan bahwa ilmu yang mempelajari tentang makna adalah semantik. Dalam ilmu semantik makna sebuah tanda terdiri atas. Pertama, makna leksikal dan gramatikal. Makna leksikal adalah makna satuan bahasa yang sesuai dengan acuannya karena proses gramatikal atau proses asosiatif contoh, leksem bunga dalam kalimat adik menanam bunga bermakna leksikal karena makna bunga itu sesuai dengan acuan sejatinya yaitu: "tanaman hias". Makna gramatikal adalah makna satuan bahasa yang timbul krena proses dan makna nonreferensial. Makna gramatikal. Kedua, makna referensial referensial adalah makna satuan bahasa yang sesuai dengan referen (acuan) satuan bahasa itu, contohnya kuda mengacu kepada binatang, sedangkan makna nonreferensial adalah makna satuan bahasa yang tidak berdasarkan pada referen tertentu. Ketiga, makna denotatif dan kônötatif. Makna denotatif adalah makna satuan bahasa yang sesuai dengan acuannya tanpa mengandung nilai rasa, baik nilai rasa positif maupun negatif. Makna konotatif adalah makna satuan bahasa yang didasarkan atas nilai rasa baik positif maupun negatif yang terkandung dalam suatu satuan bahasa. Keempat, makna kias. Makna kias adalah makna satuan bahasa yang ada dibalik makna harfiah. Kelima, makna idiomatik. Makna idiomatik adalah makna satuan bahasa yang tidak dapat ditelusuri berdasarkan makna leksikal dan makna gramatikal. 
Berdasarkan uraian tersebut, dapat disimpulkan bahwa pengembangan penguasaan kosakata siswa dengan cara menentukan makna kata dapat membantu siswa dalam meningkatkan penguasaan kosakata sebab dari menentukan makna kata siswa dapat dapat terampil dalam menulis.

\section{Pengembangan Penguasaan Kosakata dengan Cara Menentukan Pilihan Kata/Diksi}

Menurut Keraf (2009:87-111), cara pengembangan kosakata yang terakhir adalah melalui diksi. Diksi adalah ihwal ketepatan dalam pemilihan kata atau satuan leksikal untuk mengungkapkan gagasan dan kesesuaian kata atau satuan leksikal itu dengan konteks pemakainya. Kata yang tepat adalah kata yang dapat menimbulkan gagasan yang tepat pada imajinasi pendengar atau permbaca seperti yang dipikirkan atau dirasakan pembaca atau penulis.

Manaf (2008:141-143) juga menjelaskan bahwa ketepatan pilihan kata, paling sedikitnya dapat diukur berdasarkan tiga kriteria. Pertama, tepat konsep. yakni kata yang dapat mengungkapkan pengertian suatu objek secara tepat. Kedua, tepat nilai rasa, kata yang dapai mengungkapkan perasaan penutur atau penulis secara tepat. Nilai rasa ini berkaitan dengan rasa sopan, halus, teihormat, bersih, kurang dll. Ketiga, tepat konteks pemakainya. Kata yang tepat konteksnya adalah kata yang sesuai dengan kontcks pemakainya. Konteks pemakainya ini berkaitan dengan siapa yang diajak berbicara, tempatnya dimana, suasananya bagaimana, waktun ya kapan, topiknya apa, tujuannya apa, dan ragam bahasanya apa. Ketepatan konteks, juga dapat diukur berdasarkan kesesuaian pilihan kata dengan ragam bidang kegiatan. Berdasarkan ragam bidangnya terbagi atas ragam sastra ragam ilmiah, dan komunikasi sehari-hari.

Berdasarkan uraian tersebut, dapat disimpulkan bahwa diksi adalah perihal mengenai ketepatan dalam pemlihan kata. Pengembangan penguasaan kosakata siswa dengan cara menentukan pilihan kata dapat membantu siswa dalam meningkatkan penguasaan kosakata sebab dari menentukan makna kata siswa dapat dapat terampil dalam menulis.

\section{Korelasi Penguasaan Kosakata dengan Keterampilan Menulis Teks Deskripsi}

Penguasaan kosakata siswa sangat penting untuk meningkatkan keterampilan berbahasa. Keterampilan berbahasa seseorang bergantung kepada kuantitas dan kualitas kosakata yang dimilikinya (Tarigan, 2011:2). Mereka yang memiliki kemampuan yang tinggi akan memilih 
kata mana yang paling harmonis untuk mewakili maksud atau gagasannya. Salah satu keterampilan berbahasa yang harus dilkuasai oleh siswa adalah menulis teks deskripsi.

Dalam menghasilkan teks deskripsi yang baik, dibutuhkan kreativitas imajinasi yang tinggi sehingga dapat merangsang pembaca. Hal ini membutuhkan kerja keras agar dapat menata pikiran, dan memberikan alur penceritaaan yang normal, namun bersifat imajinatif sehingga menghasilkan sebuah cerita yang dapat memberikan kesenangan dan pemahaman. Sehubungan dengan hal ini, penguasaan kosakata memegang peranan penting dalam kegiatan menulia teks deskripsi. Siswa yang luas kosakatanya akan memiliki keterampilan yang tinggi untuk memilih kata mana yang paling tepat untuk mewakili maksud atau gagasannya. Sebab kualitas dan kuantitas berbahasa seseorang jelas bergantung kepada kualitas dan kuantitas kosakata yang dimilikinya. Semakin kaya kosakata yang dimiliki, semakin besar pula kemungkinan untuk terampil berbahasa. Dalam penguasaan kosakata, hal yang harus diperhatikan bagaimana cara siswa mengembangkan idenya untuk menulis teks deskripsi dan bagaimana cara mengungkapkan ide tersebut sesuai dengan kosakata yang tepat, sehingga tidak terjadi kesalahan dalam komunikasi lisan maupun tulis.

Berdasarkan uraian tersebut, keterbatasan kosakata dapat melemahkan daya ungkap seseorang terutama dalam menulis teks cerita deskripsi. Menulis teks deskripsi membutuhkan kreativitas dan imajinasi yang tinggi. Oleh karena itu, semakin tinggi penguasaan kosakata sescorang, semakin bagus kosakata yang dituangkan dalam menulis teks deskripsi.

\section{B. Penelitian yang Relevan}

Berdasarkan studi kepustakaan dan hasil-lhasil penelitian yang relevan dengan penelitian ini, ditemukan tiga penelitian yang relevan. Ketiga penelitian relevan tersebut sebagai berikut. Pertama, Restia Nelson Putri pada tahun 2014 dengan skripsi yang berjudul "Hubungan Penguasaan Kosakata dengan Keterampilan Menulis Narasi Ekposiotris Siswa Kelas VII SMP Negeri 3 Payakumbuh". Berdasarkan hasil penelitiannya dapat disimpulkan bahwa ada hubungan

yang signifikan antara penguasaan kosakata dengan keterampilan menulis narasi ekpositoris siswa kelas VII SMP Negeri 3 Payakumbuh pada taraf Signifikansi 95\% dengan derajat 
kebebasan n-2 (44-2). Dengan demikian, H0 dalam penelitian ini ditolak sedangkan H1 diterima karena hasil pengujian membuktikan bahwa t hitung lebih besar dari $t$ tabel yaitu 2,22:> 2,01.

Kedua, Ismai Putri pada tahun 2015 dengan skripsi yang berjudul "Hubungan Penguasaan Kosakata dengan Keterampilan Menulis Teks Pantun Siswa kelas XI SAMA Negeri 1 Bayang Kabupaten Pesisir Selatan". Berdasarkan hasil penelitiannya dapat disimpulkan bahwa terdapat hubungan yang signifikan antara penguasaan kosakata dengan keterampilan menulis teks pantun siswa kelas XI SMA Negeri 1 Bayang pada taraf signifikansi 96\% dengan derajat kebebasan n-1. Dengan demikian, H0 dalam penelitian ini ditolak, sedangkan Hl diterima karena hasil pengujian membuktikan bahwa thitung lebih besar dari ttabel yaitu 1,71<6,22.

Ketiga, Merry Agustir pada tahun 2018 dengan skripsi yang berjudul "Hubungan Penguasaan Kosakata dengan Kemampuan Menulis Teks Diskusi siswa kelas VII MTsN Lubuk Buaya Padang". Berdasarkan hasil penelitiannya dapat disimpulkan bahwa terdapat hubungan yang signitikan antara penguasaan kosakata dengan kemampuan menulis teks diskusi siswa kelas VIII MTsN Lubuk Buaya Padang pada taraf signifikansi 95\% dengan derajat kebebasan n-2. Dengan demikian, HO dalam penelitian ini ditolak, sedangkan HI diterima karena hasil pengujian membuktikan bahwa t hitung lebih besar dari t tabel yaitu 6.92:> 1,96

Ketiga pene!itian tersebut memiliki persamaan dan perbedaan dengan penelitian yang sedang dilakukan. Persamaanya terletak pada jenis penelitian korelasi yang dilakukan yaitu mengenai hubungan antara variabel bebas dan vaniabel terikat. Selain itu, persamaaanya juga terletak pada objek penelitiannya, yaitu meneliti penguasaan kosakata. Berikut dijelaskan satu persatu antara persamaan dan perbedaan penelitian tersebut.

\section{Kerangka Konseptual}

Dalam pembelajaran bahasa, keterampilan berbahasa merupakan aspek yang harus dikuasai oleh siswa. Salah satunya yaitu memproduksi teks. Kegiatan memproduksi teks tidak terlepas dari keterampilan menulis, terutama dalam Kurikulum 2013. Pada Kurikulum 2013 teks

yang harus dikuasai siswa salah satunya yaitu teks deskripsi. Dalam menulis teks, sangat diperlukan penguasaan kosakata supaya bahasa yang digunakan merupakan bahasa baku dan 
kalimat - kalimat yang efektif dalam menulis teks deskripsi. Secara konseptual, indikasi korelasi antara variabel tersebut dapat digambarkan sebagai berikut.

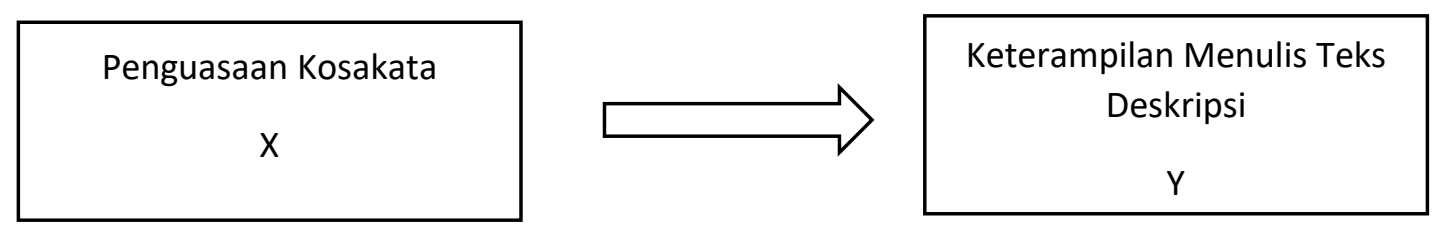

Bagan 1. Kerangka Konseptual

Keterangan:

X : Variabel Bebas

Y : Variabel Terikat

$\Longrightarrow$ : Korelasi

\section{Hipotesis Penelitian}

Berdasarkan kajian teori dan kerangka konseptual yang telah dikemukakan tersebut, maka rumusan hipotesis untuk penelitian ini sebagai berikut.

$\mathrm{H} 0=$ tidak terdapat korelasi penguasaaan kosakata dengan keterampilan menulis teks deskripsi siswa kelas VII di SMP Negeri 2 Kecamatan Gunung Omeh. H0 diterima jika thitung $<$ ttabel pada $\mathrm{dk}(\mathrm{n}-1)$ dengan taraf signifikan $95 \%$.

$\mathrm{H} 1$ = terdapat korelasi penguasaan kosakata dengan keterampilan menulis teks deskripsi siswa kelas VII di SMP Negeri 2 Kecamatan Gunung Omeh. Hl diterima jika thitung $>\mathrm{t}$ tabel pada $\mathrm{dk}$ (n-1) dengan taraf signifikan $95 \%$. 


\section{BAB III}

\section{METODOLOGI PENELITIAN}

\section{A. Jenis Penelitian}

Jenis penelitian ini adalah kuantitatif dengan metode deskriptif melalui desain korelasional. Penelitian ini dikatakan penelitian kuantitatif karena data yang diperoleh berupa angka, yaitu skor keterampilan membaca pemahaman dan skor keterampilan menulis teks deskripsi. Hal ini sesuai dengan pendapat Arikunto (2010:10) penelitian kuantitatif adalah penelitian yang digunakan untuk memperoleh informasi berupa angka mulai dari pengumpulan data, penafsiran data, hingga penampilan hasilnya.

Metode yang digunakan dalam penelitian adalah metode deskriptif dengan pendekatan korelasi. Metode deskriptif dengan pendekatan korelasi bertujuan mendeskripsikan, menganalisis, dan menginterpretasi data-data yang berupa angka kemudian menemukan ada tidaknya hubungan antara variabel yang satu dengan variabel yang lainnya. Hal ini sesuai dengan pendapat Arikunto Arikunto (2010:313) bahwa metode korelasi bertujuan menemukan ada tidaknya hubungan, dan apabila ada, berapa beratnya hubungan, serta berarti tidak hubungan tersebut. Dengan demikian, metode korelasional digunakan untuk mencari korelasi antara penguasaan kosakata dengan keterampilan menulis teks deskripsi siswa kelas VII di SMP Negeri 2 Kecamatan Gunung Omeh.

\section{B. Populasi dan Sampel}

Populasi dalam penelitian ini adalah seluruh siswa kelas VII di SMP Negeri 2 Kecamatan Gunung Omeh yang terdaftar pada tahun 2020/2021. Jumlah siswa kelas VII di SMP Negeri 2 Kecamatan Gunung Omeh yang terdaftar adalah 150 siswa yang tersebar dalam lima kelas. Menurut Arikunto (2002:112), menjelaskan jika subjek penelitian yang kurang dari 100, lebih baik diambil semuanya sebagai sampel. Namun, jika jumlah sampel subjek penelitian lebih dari 100, dapat diambil 10-15\% atau 20-25\% sebagai sampel. Dalam penelitian ini subjek penelitian lebih dari 100 sehingga sampel penelitian akan diambil 20\% dari jumlah siswa setiap kelas. Jadi, jadi dalam penelitian ini jumlah sampel adalah 30 orang. 
Teknik pengambilan sampel yang digunakan adalah teknik secara acak atau proportional random sampling. yaitu penarikan sampel berdasarkan proporsi jumlah siswa per kelas. Untuk lebih jelasnya mengenai populasi dan sampel, dapat dilihat pada tabel berikut.

\section{Tabel 1}

\section{Populasi dan Sampel Penelitian}

\begin{tabular}{|l|l|c|l|}
\hline No & Kelas & $\begin{array}{l}\text { Jumlah } \\
\text { Populasi }\end{array}$ & $\begin{array}{l}\text { Sampel } \\
(20 \%)\end{array}$ \\
\hline 1 & VII 1 & 30 orang & 6 orang \\
\hline 2 & VII 2 & 30 orang & 6 orang \\
\hline 3 & VII 3 & 30 orang & 6 orang \\
\hline 4 & VII 4 & 30 orang & 6 orang \\
\hline 5 & VII 5 & 30 orang & 6 orang \\
\hline Jumlah & 150 orang & 30 orang \\
\hline
\end{tabular}

\section{Variabel dan Data}

Penelitian ini memiliki dua variabel. Pertama, penguasaan kosakata siswa kelas VII di SMP Negeri 2 Kecamatan Gunung Omeh sebagai variabel bebas (variabel X). Kedua, keterampilan menulis teks deskripsi siswa kelas VII di SMP Negeri 2 Kecamatan Gunung Omeh sebagai variabel terikat (variabel Y). Keterkaitan antara variabel bebas dan terikat dalam penelitian ini adalah penguasaan kosakata merupakan taktor yang merupakan faktor yang mempengaruhi keterampilan menulis teks deskripsi siswa kelas VII di SMP Negeri 2 Kecamatan Gunung Omeh. Data dalam penelitian ini adalah skor hasil tes objektif untuk mengukur penguasaan kosakata siswa dan skor hasil tes unjuk kerja berupa menulis teks deskripsi untuk mengukur keterampilan menulis teks deskripsi siswa. 


\title{
D. Instrumen Penelitian
}

Instrumen penelitian adalah alat yang digunakan untuk mengukur kemampuan siswa. Instrumen yang digunakan dalam penelitian ini adalah dua bentuk tes yaitu tes objektif dan tes unjuk kerja.

\section{Tes Objektif}

Tes objektif digunakan untuk mengetahui penguasaan kosakata siswa dengan pilihan ganda (A, B, C, dan D). Sebelum dijadikan instrumen penelitian, tes diujicobakan terlebih dahulu kepada 30 orang siswa di luar sampel penelitian. Tes uji coba penguasaan kosakata terdiri atas 60 soal. Tes objektif yang diberikan kepada siswa disusun berdasarkan indikator yang telah ditetapkan, yaitu menentukan sinonim kata, menentukan antonim kata, menentukan makna kata/istilah, dan menentukan pilihan kata dalam kalimat yang berkaitan dengan ciri kebahasaan teks deskripsi. Tes penguasaan kosakata untuk kosakata umum berkaitan dengan teori Bloom ranah kognitif dalam pembentukan indikator penguasaan kosakata. Ranah kognitif merupakan segi kemampuan yang berkaitan dengan aspek-aspek pengetahuan, penalaran, atau pemikiran ( Dimayati dan Mudjiono, 2009: 298). Bloom (dalam Dimayati dan Mudjiono. 2009: 27 ), membagi ranah kognitif kedalam enam tingkatan atau kategori yatu, atau kategori yaitu, pengetahuan, pemahaman, penerapan, analisis, sintesis, dan evaluasi. Untuk kosakata umum hanya menggunkan tiga tingkatan atau kategori yaitu, pengetahuan, pemahaman, dan penerapan. Pertama, pengetahuan merupakan kemampuan mengetahui atau mengingat istilah, fakta aturan, urutan, metode dan sebagainya. Kedua, pemahaman merupakan kemampuan memecahkan masalah, membuat bagan, menggunakan konsep, kaidah, prinsip, metode, dan sebagainya. Ketiga, penerapan merupakan kemampuan memisahkan, membedakan, seperti merinci baganbagan, hubungan dan sebagainya.

\section{Tabel 4}

\author{
Kisi-kisi Uji Coba Tes Keterampilan Menulis Teks Deskripsi \\ Siswa Kelas VII SMP Negeri 2 Gunung Omeh
}




\begin{tabular}{|l|l|l|c|}
\hline No & Indikator & Nomor Soal & $\begin{array}{l}\text { Jumlah } \\
\text { Soal }\end{array}$ \\
\hline 1 & $\begin{array}{l}\text { Memahami struktur teks } \\
\text { deskripsi } \\
\text { a. Identifikasi } \\
\text { b. Deskripsi Bagian } \\
\text { c. Kesimpulan }\end{array}$ & $\begin{array}{l}1,2,8,9,12,13,15,16,17,21,22,25,30,31,33,34,36,37,39,40, \\
23,29,44,47,51 .\end{array}$ & 20 \\
\hline 2 & $\begin{array}{l}\text { Memahami isi bacaan } \\
\text { a. Menjawab pertanyaan tentang } \\
\text { isi teks } \\
\text { b. Mencari ide pokok bacaan } \\
\text { c. Meringkas isi bacaan }\end{array}$ & $\begin{array}{l}3,6,7,10,11,18,19,20,26,27,28, \\
32,35,48,49,53,54,58,59,60 .\end{array}$ & \\
\hline 3 & $\begin{array}{l}\text { Memahami makna kata bacaan } \\
4,5,14,24,25,38,41,42,45,46,50,\end{array}$ & 15 \\
\hline Jumlah & $52,55,56,57$. & $\mathbf{6 0}$ \\
\hline
\end{tabular}

Berdasarkan skor yang diperoleh pada tes uji coba tersebut, selanjutnya dianalisis validitas dan reliabilitasnya. Hal ini dilakukan agar tes yang digunakan dalam penelitian benarbenar dapat mengukur keterampilan siswa dan dapat dipertanggungjawabkan dengan kata lain tes yang telah disusun berdasarkan indikator tersebut diujicobakan untuk menentukan validitas item dar reliabilitas tes agar data yang terkumpul dapat dipertanggungjawabkan. Hal tersebut sejałan dengan pendapat Grounlund (dalam Nurgiyantoro, 2012: 150) yang menyatakan bahwa secara esensial alat tes harus memiliki kualitas validitas (validity), realibilitas (reliability), dan kebergunaan (11sabilitv) Berikut uraian imengenai validitas item dan reliabilitas tes uji coba penguasaan kosakata.

a. Validitas Item

Uji validitas item dilakukan untuk menguji valid atau tidaknya sebuah tes. Arifin (2012:179) menyatakan bahwa suatu tes dapat memberikan informasi yang sesuai dan dapat digunakan untuk mencapai tujuan tertentu, maka tes itu valid untuk tujuan tersebut. Validitas adalah derajat ketetapan suatu alat ukur tentang pokok isi atau arti sebenarnya yang diukur 
(Tuwu, 1993). Sejalan dengan pendapat Sujana dan Ibrahim (2009: 117) validitas berkenaan dengan kesanggupan instrumen mengukur isi yang harus diukur. Artinya, alat ukur tersebut mampu mengungkap isi suatu konsep atau variabel yang hendak diukur.

Jadi, validitas item dari suatu tes adalah ketepatan mengukur yang dimiliki sebutir item (yang merupakan bagian tak terpisahkan dari tes sebagai suatu totalitas), dalam mengukur apa yang seharusnya diukur lewat butir item tersebut.

Untuk menemukan validitas item dapat dilakukan dengan menggunakan rumus product memperson biserial berikut ini.

$$
R p b i=\frac{M_{p}-M_{t}}{S_{t}} \sqrt{\frac{p}{q}}
$$

Keterangan:

Rpbi $=$ validitas item yang dicari

$M_{P}=$ rerata skor tester yang menjawab benar

$\mathrm{M}_{\mathrm{t}}=$ rerata skor total

$\mathrm{S}_{\mathrm{t}}=$ standar deviasi

$\mathrm{p}=$ rerata siswa yang menjawab benar

$\mathrm{q}=$ rerata siswa yang menjawab salah

(Arikunto, 2012)

Hasil dari penggunaan rumus biserial kemudian ditafsirkan ke dalam (rtabel) untuk mengetahui valid atau tidaknya item dengan taraf signifikan 95\% dan derajat kebebasan (dk) n-1. Jika hasil yang diperoleh rhitung lebih besar dari rtabel berarti soal tersebut dikatakan valid. Sebaliknya, jika hasil yang diperoleh rhitung lebih kecil dari rtabel, berarti soal tersebut dikatakan tidak valid.

Validitas yang digunakan peneliti adalah validitas item, oleh karena itu masing-masing item/butir soal di uji dengan menggunakan product moment, jika butir soal/item valid maka layak untuk diteskan dan jika butir soal/item tidak valid maka tidak layak untuk diteskan.

b. Reliabilitas Tes 
Menurut Sukardi (2011:43), suatu instrumen evaluasi, dikatakan mempunyai nilai reliabelitas tinggi, apabila tes yang dibuat mempunyai hasil yang konsisten dalam mengukur yang hendak diukur. Reliabilitas adalah derajat ketepatan dan ketelitian atau akurasi yang ditunjukkan oleh instrumen pengukuran (Arikunto, 2006). Sebuah tes dikatakan dapat dipercaya jika tes tersebut diujikan berulang kali hasilnya relatif tetap atau kurang lebih sama. Reliabilitas tes dalam penelitian dapat ditentukan dengan teknik belah dua (split half method) jika diujikan satu kali dan jumlah item genap. Rumus yang digunakan adalah rumus product moment dan Spearman-Brown.

$$
r x y=\frac{n\left(\sum x y\right)-\left(\sum x\right)\left(\sum y\right)}{\sqrt{\left[n \sum x^{2}-\left(\sum x\right)^{2}\right] \cdot\left[n \sum y^{2}-\left(\sum y\right)^{2}\right]}}
$$

\section{Keterangan :}

rxy $=$ Koefisien korelasi antara variabel X dan Y

$\mathrm{n} \quad=$ Banyaknya peserta tes

$\Sigma \mathrm{X}=$ Jumlah skor item

$\Sigma \mathrm{Y}=$ Jumlah skor total item

$\Sigma \mathrm{XY}=$ Hasil perkalian antara skor item dengan skor total

$\Sigma \mathrm{X} 2=$ Jumlah skor item kuadrat

$\Sigma Y 2=$ Jumlah skor total kuadrat (Arikunto, 2006: 72).

Selanjutnya, hasil dari rumus product moment tersebut dimasukan ke dalam rumus Spearman-Brown berikut (Arikunto, 2012).

$$
r 11=2 r^{1 / 2} 1 / 2\left(1+r^{1 / 2} 1 / 2\right)
$$

\section{Keterangan:}

$r 11=$ koefisien reliabilitas yang sudah disesuaikan $r^{1 / 2} \frac{1}{2}=$ korelasi antara skor-skor setiap belahan tes

Hasil dari penggunaan rumus Spearman-Brown ditafsirkan ke dalam rtabel untuk mengetahui reliabel atau tidaknya tes tersebut dengan taraf signifikansi $95 \%$ dan derajat kebebasan (dk) n-1. Jika hasil yang yang diperoleh (rhitung) lebih besar 32 dari rtabel, 
berarti soal tersebut dikatakan reliabel. Sebaliknya, jika hasil yang diperoleh (rhitung) lebih kecil dari rtabel, berarti soal tersebut dikatakan tidak reliabel.

2. Tes Unjuk Kerja

Tes unjuk kerja dalam penelitian ini digunakan untuk mengukur keterampilan menulis teks deskripsi siswa kelas VII SMP Negeri 2 Kecamatan Gunung Omeh. Tes unjuk kerja disusun berdasarkan indikator. Indikator dalam penelitian ini yaitu mengembangkan struktur teks, mengembangkan isi teks, dan ciri kebahasaan teks deskripsi.

\section{E. Teknik Pengumpulan Data}

Teknik pengumpulan data yang digunakan pada penelitian ini ada dua yang disesuaikan dengan jenis data yang diperlukan. Uraiannya akan dijelaskan sebagai berikut. Pertama, siswa diminta untuk mengerjakan tes objektif. Dalam pelaksanaanya, siswa diberikan soal tes objektif berjumlah 40 butir soal beserta lembar jawaban. Sesuai petunjuk soal, siswa diminta menyilang salah satu huruf A, B, C, atau D yang dianggap benar pada lembar jawaban. Setelah semua siswa mengejarkan tes, soal dan lembar jawaban dikumpulkan untuk selanjutnya dulah berdasarkan teknik analisis data. Kedua, memberikan tes unjuk kerja untuk mengukur keterampilan menulis teks deskripsi siswa. Siswa diminta untuk menulis teks deskripsi dengan memperhatikan indikator menulis teks deskripsi. Setelah mengerjakan tes, teks deskripsi siswa dikumpulkan untuk selanjutnya dianalisis sesuai indikator penilian tes unjuk kerja.

\section{F. Uji Prasyarat Analisis Data}

Uji persyaratan analisis dilakukan untuk menentukan uji normalitas dan uji homogenitas.

\section{Uji Nomalitas}

Uji normalitas digunakan untuk mengetahui apakah data berdistribusi normal atau tidak. Uji normalitas data diiakukan dengan menggunakan uji liliefors. Uji normalitas data menggunakan uji liliefors dilakukan berpedoman pada langkah-langkah yang dirumuskan Sudjana (2013:466) berikut ini: 
a. Menyusun data $\mathrm{X} 1, \mathrm{X} 2, \mathrm{X} 3, \ldots . \mathrm{Xn}$ yang diurutkan dari data yang terkecil hingga data yang terbesar.

b. Data X1, X2, X3. ..Xn dijadikan bilangan baku Z1, Z2, Z3,...Zn, dengan rumus:

$$
X_{i}=\frac{X_{i-\bar{X}}}{S}
$$

Keterangan :

$\mathrm{Xi} \quad=$ skor yang diperoleh siswa

$\mathrm{X} \quad=$ skor rata-rata

$\mathrm{S} \quad=$ Simpangan baku

c. Dengan menggunakan daftar distribusi baku, kemudian dihitung peluang $F(Z 1)=P(Z<Z 1)$

d. Dengan menggunakan proporsi Z1, Z2, Z3,.. Zn yang lebih kecil atau sama dengan Zi, jika proporsi ini dinyatakan dengan SZi), maka :

$$
S(Z i)=\frac{\text { banyaknya } Z_{1}, Z_{2}, \ldots \ldots Z n \text { yang } \leq Z \quad 1}{n}
$$

e. Menghitung selisih F(Zi) - SZi) yang kemudian ditentukan harga mutlaknya.

f. Ambil harga yang terbesar dari harga mutlak selisih F (Zi)- S (Zi) tersebut, harga sebesar ini disebut Lo atau Lhitung. Untuk menerima atau menolak hipotesis nilai Lo yang diperoleh dibandingkan dengan nilai kritis Label kriteria diterima hipotesis yaitu data yang berdistribusi normal jika Lo $<$ Ltabel

g. Membandingkan nilai Lo dengan nilai kritis Label yang terdapat pada taraf signifikansi 0,05 . Kriterianya yaitu populasi dinyatakan berdistribusi normal jika Lohitung $<$ Ltabel-.

2. Uji Homogenitas

Homogenitas data dilakukan untuk mengetahui apakah data homogen atau tidak. Uji homogenitas data dilakukan dengan menggunakan rumus uji $\mathrm{F}$ atau perbandingan varian terbesar dengan varian terkecil. Menurut Sudjana (2005:250), pengaplikasian rumus tersebut dapat 
dilakukan dengan langkah - langkah berikut. Pertama, mencari masing-masing varian kelompok data, kemudian menghitung harga Fhitung dengan menggunakan rumus berikut.

$$
F=\frac{\text { Varian terbesar }}{\text { Varian terkecil }}
$$

Keterangan:

$\mathrm{F} \quad=$ perbandingan anatara varian terbesar dengan varian terkecil

S1 = varian kemampuan siswa terbesar

S2 = varian kemampuan siswa terkecil

Kedua, membandingkan harga Fhitung dengan harga Ftabel yang terdapat pada daftar distribusi $\mathrm{F}$ dengan $\mathrm{dk}=\mathrm{n}$ sebagai pembilang dan $\mathrm{n} 2$ sebagai penyebut pada taraf kepercayaan 95\%. Apabila Ftabel Fhitung dapat disimpulkan bahwa data homogen. Sebaliknya, jika Ftabel Fhitung dapat disimpulkan bahwa data tidak homogen.

\section{G. Teknik Penganalisisan Data}

Langkah - langkah yang dilakukan setelah data terkumpul dalam penelitian ini adalah sebagai berikut. Pertama, peneliti memeriksa hasil tes objektif dan tes unjuk kerja yang dikerjakan siswa kelas VII SMP Negeri 2 Kecamatan Gunung Omeh. Kedua, pemberian skor tes objektif yang dilakukan dengan memberikan skor 1 untuk jawaban yang benar dan skor 0 untuk jawaban yang salah. Penskoran untuk tes objektif penguasaan kosakata bersifat mutlak. Penskoran dilakukan dengan mencocokkan jawaban siswa dengan kunci jawaban. Kisi-kisi soal ditetapkan berdasarkan indikator sinonim, antonim, makna kata, pilihan kata. Hasil tes unjuk kerja keterampilan menulis teks deskripsi diperiksa berdasarkan tiga indikator, yaitu struktur teks, isi teks, dan ciri kebahasaan teks dalam teks deskripsi karya siswa. Skor yang diberikan untuk masing-masing indikator adalah 1-3. Pemberian skor dilakukan dengan menggunakan format sebagai berikut.

\section{Tabei 4}

\section{Rubrik Penilaian Keterampilan Menulis Teks Deskripsi}




\begin{tabular}{|c|c|c|c|c|}
\hline Aspek & \multicolumn{3}{|c|}{ Kinerja / Bobot } & Skor \\
\hline Penilaian & 1 & 2 & 3 & \\
\hline $\begin{array}{l}\text { Kelengkapan } \\
\text { struktur teks } \\
\text { deskripsi } \\
\text { ( identifikasi, } \\
\text { deskripsi bagian, } \\
\text { dan penutup). }\end{array}$ & $\begin{array}{l}\text { Diberikan } \\
\text { apabila teks } \\
\text { yang ditulis oleh } \\
\text { siswa hanya } \\
\text { terdapat salah } \\
\text { satu dari tiga } \\
\text { struktur teks } \\
\text { deskripsi yang } \\
\text { tepat. }\end{array}$ & $\begin{array}{l}\text { Diberikan } \\
\text { apabila teks } \\
\text { yang ditulis oleh } \\
\text { siswa hanya } \\
\text { terdapat dua dari } \\
\text { tiga struktur teks } \\
\text { deskripsi yang } \\
\text { tepat. }\end{array}$ & $\begin{array}{l}\text { Diberikan } \\
\text { apabila teks } \\
\text { yang ditulis oleh } \\
\text { siswa terdapat } \\
\text { semua struktur } \\
\text { teks deskripsi } \\
\text { yang tepat. }\end{array}$ & \\
\hline Isi teks deskripsi & $\begin{array}{l}\text { Diberikan } \\
\text { apabila memuat } \\
\text { satu atau dua } \\
\text { kalimat yang } \\
\text { berisi bervariasi } \\
\text { kata informasi } \\
\text { secara jelas dan } \\
\text { rinci sesuai } \\
\text { dengan fakta. }\end{array}$ & $\begin{array}{l}\text { Diberikan } \\
\text { apabila sudah } \\
\text { memuat tiga atau } \\
\text { empat kalimat } \\
\text { yang berisi } \\
\text { bervariasi kata } \\
\text { informasi secara } \\
\text { jelas dan rinci. }\end{array}$ & $\begin{array}{l}\text { Diberikan } \\
\text { apabila sudah } \\
\text { memuat lebih } \\
\text { dari empat } \\
\text { kalimat yang } \\
\text { berisi bervariasi } \\
\text { kata informasi } \\
\text { secara jelas dan } \\
\text { rinci. }\end{array}$ & \\
\hline $\begin{array}{l}\text { Ciri - ciri umum } \\
\text { teks deskripsi } \\
\text { ( peristiwa, } \\
\text { kesan - kesan, } \\
\text { dan imajinasi). }\end{array}$ & $\begin{array}{l}\text { Menyajikan } \\
\text { salah satu ciri - } \\
\text { ciri umum teks } \\
\text { deskripsi. }\end{array}$ & $\begin{array}{l}\text { Menyajikan dua } \\
\text { ciri - ciri umum } \\
\text { teks deskripsi. }\end{array}$ & $\begin{array}{l}\text { Menyajikan tiga } \\
\text { ciri - ciri umum } \\
\text { teks deskripsi. }\end{array}$ & \\
\hline $\begin{array}{l}\text { Ciri-ciri } \\
\text { kebahasaan teks } \\
\text { deskripsi. ( Kata } \\
\text { depan, kata }\end{array}$ & $\begin{array}{l}\text { Diberikan } \\
\text { apabila teks } \\
\text { yang ditulis } \\
\text { siswa terdapat }\end{array}$ & $\begin{array}{l}\text { Diberikan } \\
\text { apabila teks } \\
\text { yang ditulis } \\
\text { siswa terdapat }\end{array}$ & $\begin{array}{l}\text { Diberikan } \\
\text { apabila teks } \\
\text { yang ditulis } \\
\text { siswa terdapat }\end{array}$ & \\
\hline
\end{tabular}




\begin{tabular}{|l|l|l|l|l|}
\hline berimbuhan, dan & ketiga kesalahan & dua kesalahan & satu kesalahan & \\
ejaan dalam teks & ciri - ciri & ciri - ciri & ciri - ciri & \\
deskripsi). & kebahasaan teks & kebahasaan teks & kebahasaan teks & \\
& deskripsi. & deskripsi. & deskripsi. & \\
\hline
\end{tabular}

Ketiga, mengubah skort es menjadi nilai dengan menggunakan rumus presentase sebagai berikut.

$$
N=\frac{S M}{S M} X S \operatorname{Max}
$$

Keterangan:

$\mathrm{N}=$ tingkat penguasaan

$\mathrm{SM}=$ skor yang diperoleh

$\mathrm{SI}=$ skor yang harus dicapai dalam suatu tes

$\mathrm{S} \mathrm{Max}=$ skala yang digunakan

( Arikunto, 2003:236)

Keempat, menafsirkan hasil tes siswa mengenai penguasaan kosakata dengan keterampilan menulis teks deskripsi berdasarkan nilai rata - rata hitung dari masing - masing tes. Berikut ini rumus yang digunakan.

$$
M=\frac{\sum F X}{N}
$$

Keterangan:

$\mathrm{M} \quad=$ mean (rata-rata hitung)

$\mathrm{N} \quad=$ jumlah sampel

$\Sigma F X \quad=$ jumlah nilai keseluruhan

Kelima, mengklasifikasikan hasil tes dengan menggunakan skala 10 pada tabel 5.

Tabel 5

Pedoman Konversi Nilai Siswa dengan Skala 10 


\begin{tabular}{|l|l|l|l|}
\hline No. & Tingkat Pemahaman & $\begin{array}{l}\text { Nilai Ubahan Skor } \\
\mathbf{1 0}\end{array}$ & Kualifikasi \\
\hline 1 & $96 \%-100 \%$ & 10 & Sempurna \\
\hline 2 & $86 \%-95 \%$ & 9 & Baik Sekali \\
\hline 3 & $76 \%-85 \%$ & 8 & Baik \\
\hline 4 & $66 \%-75 \%$ & 7 & Lebih dari Cukup \\
\hline 5 & $56 \%-65 \%$ & 6 & Cukup \\
\hline 6 & $46 \%-55 \%$ & 5 & Hampir Cukup \\
\hline 7 & $36 \%-45 \%$ & 4 & Kurang \\
\hline 8 & $26 \%-35 \%$ & 3 & Kurang Sekali \\
\hline 9 & $16 \%-25 \%$ & 2 & Buruk \\
\hline 10 & $0 \%-15 \%$ & 1 & Buruk Sekali \\
\hline
\end{tabular}

Nurgiyantoro (Abdurahman \& Ratna, 2003)

Keenam, membuat diagram batang penguasaan kosakata dan keterampilan menulis teks deskripsi secara umum dan per indikator.

Ketujuh, melakukan uji persyaratan analisis data yaitu uji noramalitas dan uji homogenitas data.

Kedelapan, mengkorelasikan nilai tes penguasaan kosakata dengan tes keterampilan menulis teks deskripsi menggunakan rumus korelasi product moment berikut.

$$
r x y=\frac{N\left(\sum x y\right)-\left(\sum x\right)\left(\sum y\right)}{\sqrt{\left[n \sum x^{2}-\left(\sum x\right)^{2}\right] \cdot\left[n \sum y^{2}-\left(\sum y\right)^{2}\right]}}
$$

Keterangan :

rxy $\quad=$ Koefisien korelasi antara variabel bebas penguasaan kosakata $(\mathrm{X})$ dan variabel terikat menulis teks deskripsi $(\mathrm{Y})$

$\mathrm{N} \quad=$ Jumlah sampel

$\Sigma \mathrm{xy} \quad=$ Jumlah perkalian variabel $\mathrm{x}$ dan variabel $\mathrm{y}$

$\Sigma x^{2} \quad=$ Jumlah kuadrat $\mathrm{x}$

$\Sigma y^{2}=$ Jumlah kuadrat $\mathrm{y}$ 
Kesembilan, menguji kebeartian hipotesis. Keberartian hipotesis Menurut Arikunto (2002:167) dapat dicari dengan rumus berikut.

$$
t=r \frac{\sqrt{n-1}}{\sqrt{1-r^{2}}}
$$

Keterangan:

$\mathrm{t}=$ besaran pengujian hipotesis

$\mathrm{r}=$ besarnya koefisien korelasi

$\mathrm{n}=$ jumlah sampel

Kesepuluh, membahas analisis dan membuat kesimpulan tentang hasil pembahasan dengan cara mendeskripsikan korelasi penguasaan kosakata dengan kerampilan menulis teks deskripsi siswa kelas VII di SMP 2 Kecamatan Gunung Omeh. 


\section{DAFTAR PUSTAKA}

Abdurrahman dan Ellya Ratna. 2003. Evaluasi Pembelajaran Bahasa dan Sastra Indonesia Buku Ajar) (pp. 36, 264-265). Padang: FBS UNP.

Adiningsih, Y. (2015 ). Hubungan Penguasaan Kosakata dengan Kemampuan Menulis Karangan Narasi pada Siswa Kelas VII SMP Islam Ibnu Sina Pamijahan Bogor . Jurnal Lingua.

Andayani, dkk. 2015. "Hubungan antara Penguasaan Kosakata dan Motivasi Belajar dengan Keterampilan Menulis Teks Narasi pada Siswa Kelas XI SMK Negeri 1 Sawit Boyolali". Basatra Jurnal Penelitian Bahasa, Sastra Indonesia dan Pengajarannya. Volume 3 nomor 23, April 2015. Issn 12302-6405.

Alwi, Hasan dkk. 2003. Tata Bahasa Baku Bahasa Indonesia 1. Jakarta: Balai Pustaka.

Arikunto, Suharsimi. 2006. Prosedur Penelitian Suatu Pendekatan dan Praktik Edisi Revisi VI. Jakarta : Rineka Cipta.

Arikunto, Suharsimi. 2010. Prosedur Penelitian (Suatu Pendekatan Praktek) Jakarta: Rineka Cipta.

Arikunto, Suharsimi. 2012. Dasar-dasar Evaluasi Pendidikan. Jakarta: Bumi Aksara.

Chaer, Abdul. 2007. Leksikologi dan Leksikografi Indonesia. Jakarta: Rineka Cipta.

Chaer, Abdul. 2009. Semantik Bahasa Indonesia. Jakarta: Rineka Cipta.

Delfianto. 2016. "Kontribusi Kemampuan Membaca Pemahaman dan Penguasaan Kosakata terhadap Keterampilan Menulis Teks Tanggapan Deskriptif". Jurnal Pendidikan Rokania. 1 No. 2, 43-45. (Online). (https://e- jurnal.stkiprokania.ac.id diunduh pada tanggal 2 Oktober 2021).

Dewi, Triwina Santi. 2018. "Korelasi Pemahaman Kosakata Bidang Pendidikan dengan Keterampilan Menulis Teks Eksposisi Siswa Kelas X SMK Negeri 1 Payakumbuh".

Jurnal

Pendidikan Bahasa dan Sastra Indonesia, Vol. 7 No. 3, 385-393. (Online).

Dini, Rahma. 2017. Hubungan Penguasaan Kosakata Bidang Jurnalistik dengan Keterampilan Menulis Teks Berita Siswa Kelas XII SMK Negeri 2 Bukittinggi". Jurnal Pendidikan Bahasa dan Sastra Indonesia, Vol. 6 No. 257-263. (Online). (http://ejournal.unp.ac.id diunduh pada tanggal 4 November 2021).

Faldini, M. (2017). Kewirausahaan Sosial dalam Pemberdayaan Ekonomi Umat. Jurnal Dakwah dan Pengembangan Sosial Kemanusiaan, 126-139. 
Gani, Erizal. 1999. "Pembinaan Keterampilan Menulis di Perguruan Tinggi." (Buku Ajar).Padang:

DIP Proyek UNP. 2013. Bahasa Karya Tulis llmiah. Padang: UNP Press.

Handayani., T. (2015). Kontribusi Penguasaan Kosakata terhadap Keterampilan Menulis Teks Deskripsi Siswa Kelas VII SMP Negeri 2 Bukittinggi. 1.

Harsiati, Titik dkk. 2016. Bahasa ndoenesia Edisi Revisi. Buku Siswa. Kementrian Pendidikan dan

Kebudyaaan. Hasrar, A. D. (2018). Hubungan Penguasaan Kosakata dengan Keterampilan

Menulis Karangan Deskriptif Bahasa Jerman Siswa. Eralingua: Jurnal Pendidikan Bahasa Asing dan Sastra, 32-40.

Nadila Ridwan, U. A. (2019). Hubungan Penguasaan Kosakata Bahasa Indonesia dengan Kemampuan Menulis Teks Narasi Siswa Kelas VII SMP Negeri 2 Sunnguminasa.

Nurgiayantoro, Burhan. 2004. Sastra Anak: Persoalam Genre. FBS, UNY Volume 16, No 2, Juni 2004; 107- 122. 2012. Tcori Pengkajian Fiksi. Yogyakarta. Gajah Mada University Press.

Pateda, Mansoer. 1995. Kosakata dan Pengajarannya. Ende Flores: Nusa Indah.

Putri, Ismai. 2015. "Hubungan Penguasaan Kosakata dengan Keterampilan Menulis Teks Pantun Siswa Kelas XI SMA Negeri I Bayang Kabupaten Pesisir Selatan". (skripsi) Padang:

FBS

UNP.

Putri, Restia Nelson. 2014. Hubungan Penguasaan Kosakata dengan Keterampilan Menulis Narasi

Ekposiotris Siswa Kelas V!! SMP Negeri 3 Payalumbuh". (skripsi) Padang: FBS UNP.

Pramesti, Utami Dewi. 2015. Peningkatan Penguasaan Kosakata Bahasa Indonesia dalam Keterampilan Membaca Melalui Teka-Teka Silang UNP. Jurnal Puitika, Volume 11.

Rianti, Maya. 2013. "Hubungan Penguasaan kosakata dengan Keterampilan Menulis Karangan Argumentasi Siswa kelas XIl IPS SMA Negeri 1 Guguak Kabupaten 50 Kota". (Skripsi) Padang: FBS UNP.

Rintik Sunariati, E. I. (2019). Hubungan Antara Penguasaan Kosakata dan Struktur Kalima dengan

Kemampuan Menulis Karangan Narasi. Jurnal Pendidikan Bahasa, 309-327.

Sherlina Jamal, S. M. (2018). Kemampuan Menulis Teks Deskripsi Berdasarkan Pengamatan Langsung Siswa Kelas VII SMP Negeri 3 Sungguminasa Kabupaten Gowa. Jurnal Pendidikan Bahasa dan Sastra Indonesia, 1-10. 
Sujana, Nana dan Ibrahim. 2009. Penelitian dan Penilaian Pendidikan. Bandung: Sinar Baru Algendindo.

Sukardi. 2006. Penelitian Kualitatif-Naturalistik dalam Pendidikan. Yogyakarta: Usaha Keluarga.

Tressyalina, A. P. (2 Juni 2019; Seri A ). Kontribusi Penguasaan Kosakata Bidang Lingkungan terhadap Keterampilan Menulis Teks Deskripsi Siswa Kelas VII SMP Negeri 2 Padang Panjang. Jurnal Pendidikan Bahasa dan Sastra Indonesia, Vol. 8 No., , 8-13.

Tuwu, Alaudin. 1993. Pengantar Metode Penelitian. Jakarta: Universitas IndonesiaI Press.

Yesi Septriyanti, E. A. (2012). Hubungan Penguasaan Kosakata dengan Keterampilan Menulis Argumentasi Siswa Kelas X SMA Negeri 6 Padang. Jurnal Pendidikan Bahasa dan Sastra Indonesia, Seri E 339- 425. 